\title{
Tulane
}

Tulane Economics Working Paper Series

\section{Do Government Subsidies to Low-income Individuals Affect Interstate Migration? Evidence from the Massachusetts Health Care Reform}

\author{
James Alm \\ Department of Economics \\ Tulane University \\ jalm@tulane.edu
}

\author{
Ali Enami \\ Department of Economics \\ Tulane University \\ aenami@tulane.edu
}

Working Paper 1703

Jul 2017

\begin{abstract}
Following the passage of the Patient Protection and Affordable Care Act (ACA) of 2010, many but not all - states decided to expand their Medicaid program in line with provisions of the new law. Will low-income individuals respond to the incentives of living in a state with better health subsidies by relocating to the state? This paper addresses this question by examining the population growth rate of low-income individuals in Massachusetts following the Massachusetts Health Care Reform (MHCR) of 2006. Like the ACA, the MHCR expanded the Medicaid program, and also provided subsidized health insurance for low-income individuals. Using difference-in-differences and tripledifferences models and Internal Revenue Service tax return data, we show that the reform did not have a global effect on the movement of low-income individuals across all cities in Massachusetts. However, we also show that the reform did have a local (or border) effect on the movement into border cities of the state, an effect that is relatively large for cities very close to the border but disappears quickly once the distance to border goes beyond 15 miles.
\end{abstract}

Keywords: Massachusetts health care reform, interstate migration, Medicaid expansion, subsidized health insurance, border analysis

JEL codes: H24; I13; J11 


\title{
Do Government Subsidies to Low-income Individuals Affect Interstate Migration? Evidence from the Massachusetts Health Care Reform ${ }^{1}$
}

\author{
James Alm ${ }^{2}$ and Ali Enami ${ }^{3}$
}

\begin{abstract}
Following the passage of the Patient Protection and Affordable Care Act (ACA) of 2010, many - but not all - states decided to expand their Medicaid program in line with provisions of the new law. Will low-income individuals respond to the incentives of living in a state with better health subsidies by relocating to the state? This paper addresses this question by examining the population growth rate of low-income individuals in Massachusetts following the Massachusetts Health Care Reform (MHCR) of 2006. Like the ACA, the MHCR expanded the Medicaid program, and also provided subsidized health insurance for low-income individuals. Using difference-in-differences and triple-differences models and Internal Revenue Service tax return data, we show that the reform did not have a global effect on the movement of low-income individuals across all cities in Massachusetts. However, we also show that the reform did have a local (or border) effect on the movement into border cities of the state, an effect that is relatively large for cities very close to the border but disappears quickly once the distance to border goes beyond 15 miles.
\end{abstract}

Keywords: Massachusetts health care reform, interstate migration, Medicaid expansion, subsidized health insurance, border analysis

\section{JEL classification: H24; I13; J11}

\footnotetext{
${ }^{1}$ We are grateful to Daniel McMillen, two anonymous referees, Alan Barreca, Michael Darden, and participants of the seminar series in the Department of Economics at Tulane University for their helpful comments on previous drafts of this paper. This research did not receive any specific grant from funding agencies in the public, commercial, or non-for-profit sectors.

${ }^{2}$ Corresponding author: Department of Economics, Tulane University, 6823 St. Charles Avenue, 208 Tilton Hall, New Orleans, LA 70118. Phone: +1 504862 8344; fax +1 504865 5869; email jalm@ tulane.edu .

${ }^{3}$ Department of Economics, Tulane University. Email: aenami@tulane.edu.
} 


\title{
Do Government Subsidies to Low-income Individuals Affect Interstate Migration? Evidence from the Massachusetts Health Care Reform
}

\author{
James Alm and Ali Enami
}

Research Highlights

- Will low-income individuals move to a state with better health subsidies?

- This paper estimates the migration impact of the 2006 Massachusetts health care reform.

- We use difference-in-differences and triple-differences models, with tax return data.

- We find that the reform had no global effect on the overall movement into the state.

- We also find that the reform had a border effect on cities closest to the state's borders. 


\section{$\underline{\text { 1. Introduction }}$}

Government taxes and subsidies have been long debated as influential factors in shaping individual behavior (Bovenberg and Jacobs, 2005; Headey et al., 2000; Giulietti and Wahba, 2012). One behavioral dimension is individual mobility. Public assistance programs whose generosity varies across states may create incentives for individuals to move from one location to another in order to benefit from greater transfers, a phenomenon that is at the heart of the theory of the "welfare magnet" (Nannestad, 2007; Giulietti and Wahba, 2012). While the costs of relocation are usually so high that welfare programs are seldom found to be a primary reason for international_movements (Giulietti and Wahba, 2012), intra-country (or interstate) movements in response to welfare programs of different magnitudes across states are more likely, especially in decentralized political systems such as the United States (Kaestner et al., 2003; De Jong et al., 2005). The relocation of individuals motivated by government welfare programs is normally viewed as undesirable since relocation creates an extra financial burden for the host region, and may in fact lead to a "race to the bottom" in the provision of such transfers (Brueckner, 1999; Bailey and Rom, 2004). Examining the potential significance of different welfare programs in attracting new residents to a state is of primary importance for public officials.

In this paper we examine the impact of government subsidies on individual mobility, focusing on the effects of the 2006 health care reform in Massachusetts. Specifically, we examine whether the provision of free or subsidized health insurance for low-income individuals, enacted as part of the 2006 Massachusetts Health Care Reform (MHCR), created a positive netflow of low-income individuals to Massachusetts. This is especially relevant in the current and ongoing debate about the 2010 Patient Protection and Affordable Care Act (ACA). By mid-2017 only 32 states (including the District of Columbia) had expanded their Medicaid program in line 
with ACA (Families USA, 2017), leaving the low-income residents of the remaining states outside of this ACA safety net. Will individuals move between states in response to different state participation in the ACA? Of some importance, if the ACA is repealed but some states continue to cover their low-income individuals, will the low-income households who lose their Medicaid coverage move to more generous states?

The MHCR provides an opportunity to address these questions given that the MHCR is the benchmark for the ACA (Schwartz and Sommers, 2014) and that it provides a model that more generous states are likely to follow even if the ACA is repealed. More generally, the MHCR provides an opportunity to examine how differential state provision of welfare benefits and in particular health subsidies affect the movement of low-income individuals across state borders.

We utilize two different approaches to examine whether the MHCR affected the population of low-income individuals in Massachusetts, a "global analysis" and a "border analysis". In our global analysis, we follow important previous empirical work on the MHCR by Schwartz and Sommers (2014), focusing on the global, or state-wide impact, of the reform. Using aggregated tax return data from the Internal Revenue Service (IRS), we compare the population growth rate of low-income individuals in cities of Massachusetts to the growth rate in cities of the neighboring states of Connecticut and Rhode Island, using a difference-indifferences (DID) model. For a robustness check, we add a third dimension in triple differences estimates (or the population growth rate of high-income individuals), to better account for any state-specific but non-reform-related changes in the population of residents of these states. Like Schwartz and Sommers (2014), we find no robust global effect of the reform. 
Importantly, however, we also conduct a "border analysis", using an approach that is, to the best of our knowledge, unique to this paper. In contrast to the more aggregate global analysis, here we take a finer geographic look at migration in the border cities of Massachusetts, in order to determine whether the reform led to an increase in the population of low-income individuals in Massachusetts towns that border nearby states, for which the costs of moving into Massachusetts seem especially low. Categorizing "border cities" based on their distance to the border in 5-mile bands (from 0-5, 5-10, 10-15, 15-20, and 20-25 miles of Massachusetts state borders), we again employ DID models that compare the population growth rate of low-income individuals in border versus non-border cities of Massachusetts. For robustness checks we again utilize triple-differences models in which either the population growth rate of high-income individuals in Massachusetts or the population growth rate of low-income individuals in Connecticut and Rhode Island is the third dimension. In contrast to our global analysis, we now find compelling evidence that border cities of Massachusetts experienced a statistically significant increase in the growth rate of their low-income population following the MHCR. The effect is as large as an additional 18 to 25 percentage points growth in low-income residents for cities within 0-5 miles of the border. However, this impact disappears quickly as the distance to the border increases, so that there is no robust effect on cities that are located beyond 15 miles of the Massachusetts border. The total number of new low-income residents in all border cities amounts to about 21 thousand to 40 thousand individuals, with an associated additional financial burden of about 1-2 percent of the total $\$ 1.3$ billion budget cost of MHCR in 2007. Additional robustness checks (e.g., including neighboring states in addition to Connecticut and Rhode Island, conducting pseudo- or placebo-treatment effect analyses of the growth rate of the high income population) confirm these results. 
Our paper makes several contributions to the literature. We introduce a new, more detailed, and more disaggregated analysis of the migration impact of health subsidies to lowincome individuals. Previous studies on welfare migration are mainly limited to the case of the Aid to the Families with Dependent Children (AFDC) program (McKinnish, 2005, 2007) or the minimum wage (McKinnish, 2017). A recent paper by Schwartz and Sommers (2014) on health subsidies is an important exception, and our paper provides additional empirical evidence for the effect of health subsidies on migration. Moreover, our border analysis has not been utilized before in this literature in the context of the health subsidies, although previous papers have utilized the border analysis for cash transfer programs such as AFDC (McKinnish, 2005, 2007). We also use IRS data in our analysis, data that have not been utilized before to examine population movements due to the Massachusetts reform.

In section 2 we review the determinants of interstate migration and also the features of the MHCR, including its incentives for interstate migration. Section 3 introduces our methods, and section 4 discusses our new IRS data base. We present our results in section 5 and our conclusions in section 6 .

\section{Literature Review}

\section{Determinants of Interstate Migration}

The interstate migration literature attempts to explain state population growth using a wide variety of economic variables, including: measures of economic opportunity (McHugh and Gober, 1992; Walker, 1994; Allard and Danziger, 2000; Brueckner, 1999; Beeson et al., 2001; Anjomani, 2002; Eeckhout 2004; McKinnish, 2005, 2007, 2017; Cebula and Alexander, 2006; Sasser, 2010; Bayer and Juessen, 2012); tax burdens (Walker, 1994; Allard and Danziger, 2000; 
Anjomani, 2002; Cebula and Alexander, 2006); public subsidies and expenditures, especially expenditures on welfare programs and public schools (Walker, 1994; Allard and Danziger, 2000; Cebula and Alexander, 2006); environmental factors such as temperature (Beeson et al., 2001; Anjomani, 2002; Cebula and Alexander, 2006); crime rates (Walker, 1994; Anjomani, 2002); distance between one's home and a potential destination (Anjomani, 2002); job- and house-lock effects (Modestino and Dennett, 2013; Garthwaite et al., 2014; Foote, 2016); and factors that create a sense of community, such as proximity to family and friends or to people of the same politics, culture, religion, race, ethnicity, and even income level (Allard and Danziger, 2000; Gurak and Kritz, 2000; Anjomani, 2002; Cebula and Alexander, 2006). These variables typically are found to have the expected impact on individuals' decisions to move, although being lowincome tends not to hinder at least short-distance movements (Allard and Danziger, 2000).

Focusing on health subsidies as one potential factor for interstate migration, Bailey and Rom (2004) find that states tend to display a "race to the bottom" for health subsidy programs such as Medicaid, attracting the "wrong" individuals (e.g., low-income individuals). Overall, however, there is no consensus in the empirical literature on the significance of health benefits as a welfare magnet. For example, recent studies report somewhat contradictory results with regard to whether more generous health benefits attract people from other states. Cebula and Clark (2013) find a positive effect of Medicaid generosity on interstate migration, and Conway and Houtenville (2003) find Medicaid expenditure to be a factor that prevents the elderly population from moving out of the generous states. At the same time, Conway and Houtenville (2003) also find that Medicaid does not attract elderly residents of other states. Yang and Wallace (2007) also find somewhat conflicting results on whether public benefits like health subsidies affect the choice of immigrants on which state to reside. In an important recent study, Schwartz and 
Sommers (2014) find no evidence for a positive effect of increased health benefits for lowincome individuals on interstate migration of this group. Overall, the empirical literature provides no conclusive results about whether health benefits are a welfare magnet for interstate migration.

Note, however, that access to health insurance has been found to be an important factor shaping the decision to stay in a job or to work full time in order to benefit from employerprovided health insurance (Garthwaite et al., 2014). This finding suggests that access to publicly provided health insurance may motivate low-income individuals to move if they do not have access to or cannot afford employer-provided health insurance.

\section{The Massachusetts Health Care Reform}

Massachusetts is the first state in U.S. history to implement a nearly universal health insurance policy through what is known as the Massachusetts Health Care Reform (MHCR), signed into law on 12 April 2006 (Holahan and Blumberg, 2006; Mehren, 2006; Blendon et al., 2008). ${ }^{4}$ Its passage resulted in an increase in the percentage of insured people from 86.6 percent in 2006 to 94.2 percent in 2010 without any sign of a crowding out effect, especially with respect to those who were insured through private employers (Long et al., 2012).

The reform provided free health care for low-income individuals through the expansion of the Medicaid program; it also offered subsidized insurance for those who were not eligible for the free care but who were financially vulnerable (McDonough et al., 2008). ${ }^{5}$ Specifically, the Medicaid program (known as MassHealth in Massachusetts) was expanded to include children of

\footnotetext{
${ }^{4}$ The official title is "An Act Providing Access to Affordable, Quality, Accountable Health Care" (McDonough et al., 2006).

${ }^{5}$ The reform expanded the coverage of the Medicare program to children who live in families with income up to 300 percent of the federal poverty line, it increased covered procedures (e.g., dental procedures) for adults, and it also provided subsidized health insurance for those who were not eligible for free care who had income up to 300 percent of the federal poverty line (McDonough et al., 2008).
} 
families with income up to 300 percent of the federal poverty line (FPL) and also to offer additional benefits (mainly dental and vision care) to covered adults. Subsidized health insurance was also provided for adults who make up to 300 percent of the FPL (McDonough et al., 2008). ${ }^{6}$ The reform was especially attractive for people who were previously eligible for the Medicaid program but who were not enrolled. Long (2008) lists the key components of the reform and the specific income group that was targeted in each component, and she shows that those who made less than 150 percent of the FPL were part of the target group for most of the components. Some examples are: an expansion of the MassHealth Insurance Partnership Program, which provides insurance subsidies and employer tax credits to workers in small firms to 300 percent of poverty; an increase in enrollment caps for MassHealth programs for long-term unemployed adults (eligible up to 100 percent of FPL), disabled working adults (eligible at any income level), and people with HIV (eligible up to 200 percent of FPL); and the restoration of dental, vision, and other MassHealth benefits to adults (Long, 2008). In addition, the MHCR had some other features that led many previously eligible but not enrolled individuals to apply for the MassHealth (McDonough et al., 2008), such as the use of a single application form, outreach grants to community groups, restrictions on the availability of hospital charity care reimbursement, and the individual mandate. ${ }^{7}$

Several studies report various positive effects of this reform, many of which can be considered indicative of a higher probability of interstate migration to Massachusetts for individuals with lower income. These positive effects include such indicators as a lower financial

\footnotetext{
${ }^{6}$ The federal poverty line in 2005 (the year before the reform) was $\$ 9570$ per annum for a one-individual family, with $\$ 3260$ for each additional member (ASPE, 2005)

${ }^{7}$ Note that there is no "length of stay" residency requirement since the individual mandate that requires every resident of Massachusetts to have insurance does not include "length of stay" as part of the residency definition. See http://bluecrossfoundation.org/content/section-12-part-1-individual-mandate-definitions. Note also that Medicaid programs in all states do not have a length of stay residency requirement, so one can move to a state and immediately become eligible for its Medicaid program. See http://www.seniorlaw.com/medicaid-frequently-askedquestions/.
} 
burden of health care costs on individuals (Long, 2008; Miller 2012c), better access to health care for minorities and families with lower income, lower mortality rates for these groups (Zhu et al., 2010; Courtemanche and Zapata, 2014; Sommers et al., 2014), and better health care for children (Kenney et al., 2010; Miller, 2012b). These effects are the direct results of higher utilization of preventive health care along with lower use of emergency rooms (Smulowitz et al., 2011; Miller, 2012a; Kolstad and Kowalski, 2012; Long et al., 2012), as well as from an increase in the total factor productivity of hospitals (Thompson et al., 2012), including lower patient turnover (Shindul-Rothschild and Gregas, 2013).

However, there could be offsetting effects. While access to health care, especially for low-income individuals, positively contributes to the probability of interstate migration, the reform could also lead to a reduction in the number of jobs due to the employer mandate of the reform, which would have a negative impact on the probability of migration. Still, there are reasons to believe that the job loss may not be an important concern for the case of the MHCR. Gabel et al. (2008) report that in 2007 employers displayed strong support for the reform, and Greenhalgh-Stanley and Rohlin (2014) find evidence for only a small adverse effect of the MHCR on the number of new small firms in a short period after the reform, with no significant impact on the number or vacancies of existing firms.

While the MHCR has been studied from different perspectives, there is little systematic analysis of its effects on the population of low-income individuals to this state. To the best of our knowledge, only an important recent paper by Schwartz and Sommers (2014) has looked at its effect on the interstate migration to Massachusetts. Using individual-level data from the Annual Social and Economic Supplements (ASEC) of the Current Population Survey (CPS), they consider health care reforms in four states, including Massachusetts, and find no evidence for a 
change in interstate migration to these states. However, Schwartz and Sommers (2014) are not able to control for the characteristics of the cities to which individuals migrated since they use only state level variables. More importantly, their data do not allow them to identify the destination of movers other than this destination is located somewhere within the state of Massachusetts. The latter feature prevents them from conducting any analysis that is not a global, or a state-wide, analysis. Our paper tackles this issue using a different approach and also a different data base. These innovations allow us to evaluate the global effect of the reform on all cities of Massachusetts, similar to the work of Schwartz and Sommers (2014), but our innovations also allow us to look at more local effects of the reform on border cities of the state, something that has not previously been examined. We provide more information about our approach and our data in the next sections.

\section{Methods}

An individual's decision to move from one location to another can be modeled as a simple cost-benefit decision. For an individual to move from location A to B, the utility of living in location B has to be more than the sum of the utility of living in location A and the disutility that is created due to the costs of moving from A to B, including any monetary and nonmonetary attributes of living in a location as well as all costs of moving. Some important elements that determine an individual's decision to move are not measurable by monetary values, such as attachment to a location due to the presence of family and friends or to the psychological pressures of starting life in a new place.

Any element that changes the utility in location A, the utility in location B, or the costs of movement could affect an individual's decision to relocate. Some examples of changes in a 
potential destination that increase the probability of in-migration are the prospects of finding a better job in the new location, an increase in expenditures on public schools in the new location relative to the current location, and a reduction in the number of crimes in the new location relative to the current location. Of note, since the MHCR provided free or subsidized health insurance for low-income individuals who live in Massachusetts, it seems likely that low-income individuals would be more likely to relocate to Massachusetts as a result of this reform. The effect could be global and observable throughout all cities in Massachusetts, local and limited to border cities of this state or completely ignorable. Of course, the actual magnitude of any mobility remains an empirical question. The models that we utilize are designed to estimate the magnitude of impact.

We use several approaches to estimate the mobility impacts. The first approach uses a difference-in-differences (DID) methodology, and compares the population growth of lowincome individuals in Massachusetts to Connecticut/Rhode Island to determine whether there is any extra population growth for this income group in Massachusetts following the MHCR. We call this first approach the "global analysis".

The simplest form of the global analysis model is displayed in equation (1):

Pop growth rate $c t=\alpha+\beta_{1}$ After reform $+\beta_{2} M A+\delta$ Treatment GDID $+X \theta+$ City $_{c}+\varepsilon_{c t},(1)$

where Pop growth rate grt $_{\text {is }}$ the population growth rate of the relevant income group in city $c$ in year $t$, After reform is an indicator for the year after the reform (i.e. 2007), $M A$ is an indicator that shows whether a city is in Massachusetts (as opposed to Connecticut or Rhode Island), Treatment GDID is an interaction term between After reform and $M A$ (with $G$ denoting the global analysis and DID denoting the simple difference-in differences approach), $X$ is a vector of control variables (including the percentage change in: unemployment rate of a city, violent 
crimes in a county, per pupil public expenditures of a county, average wage across industries in a county, and a set of "flag" variables for any city with missing value for one of these control variables $^{8,9}$ ), City $_{c}$ captures city fixed effects (added to some specifications in which it replaces $M A$, a variable that is constant for each city over time), $\varepsilon_{i t}$ is the white noise error term, and other parameters $\left(\alpha, \beta_{1}, \beta_{2}, \delta, \theta\right)$ are the coefficients of variables. As discussed later in the Data section, we use data for two years, 2005 and 2007 (or the years before and after the implementation of the MHCR), mainly to avoid potential confounding effects of the "Great Recession”, whose duration was from December 2007 through June 2009. We also include in some specifications city fixed effects to deal with time invariant characteristics of each city. These time invariant variables only need to be constant for the short period of time between 2005 and 2007.

Equation (1) uses cities in Connecticut and Rhode Island as the control group, following the approach in previous work on the MHCR by Schwartz and Sommers (2014). These neighboring states are potentially affected by the reform in Massachusetts, and their low-income population is more likely to move to Massachusetts following the MHCR. This means that the model has a positive bias in estimating any effect for the reform. Therefore, the failure to find any robust effect for the reform increases one's confidence in the results; that is, if one cannot find any effect for the reform, despite the fact that the methodology over-estimates any potential effect, then this result suggests that the reform had no effect in the first place. As we discuss later, we in fact find this no-effect result for our global analysis models. One explanation for why

\footnotetext{
${ }^{8}$ In the estimations presented here, we impute "zero" for any missing control variable, and we identify these observations using the set of "flag" variables described above. Note that our results remain robust when we drop cities with missing values for any of the control variables.

${ }^{9}$ With the exception of the unemployment rate, the control variables in the vector $X$ are available only at the county level. For example, violent crimes are not reported for every city in a county, so the total number of (reported) violent crimes in a county is assigned to all cities in that county.
} 
we do not find a mobility effect in our global analysis is that, despite the features in the MHCR, the Medicaid programs in other states may still be of sufficient quality for most low-income individuals so that the presence of the Massachusetts reform does not create an incentive to move to Massachusetts. Note that in some robustness tests we expand the states to include all neighboring states of Massachusetts (e.g., Connecticut, Rhode Island, New Hampshire, New York, and Vermont), as discussed later.

The main limitation of the global analysis model of equation (1) is that any uncontrolled variable (some of which are not observable) that changes at the time of the reform could potentially confound the results. This problem can be addressed by employing a tripledifferences model that uses the population growth rate of high-income individuals as the third dimension, since the reform has no specific benefit for the high-income group. The tripledifferences global analysis model is specified in equation (2):

$$
\begin{aligned}
& \text { Pop growth rate } \text { gct }=\alpha+\beta_{1} \text { After reform }+\beta_{2} \text { Low income }+\beta_{3} M A+ \\
& \qquad \begin{array}{l}
\beta_{4}(\text { After reform } * \text { Low income })+\beta_{5}(\text { After reform } * M A)+\beta_{6}(\text { Low income } * M A) \\
+\delta \text { Treatment } G 3 D+X \theta+\text { City }_{c}+\varepsilon_{\text {gct }},
\end{array}
\end{aligned}
$$

where the new variables are Low income (a dummy variable that identifies whether a specific population group is making less than $\$ 10 \mathrm{~K}$ a year as opposed to making more than $\$ 100 \mathrm{~K}$ a year) and Treatment G3D (a triple-differences interaction term using After reform, Low income, and $M A$ ). The subscript $g$ refers to a specific income group, taking only two values corresponding to the low- and high-income groups). Other variables are defined as before. Note that City $_{c}$ is only added to some specifications as a replacement for $M A$, as before.

One important limitation of the global analysis models in equations (1) and (2) is that they may not identify any robust "global effect" of the reform on the population growth rate of 
low-income individuals in Massachusetts because only the global, or state-wide, effects of the MHCR are captured. Consequently, we also utilize a second approach to better determine whether the reform has any local, or border, effects. This second approach focuses more specifically on border cities, and is termed the "border analysis".

The border analysis models also include both DID and triple-differences specifications, but now with a focus on the growth rate of the low-income population in border towns of Massachusetts. The DID border analysis model compares the population growth rate of lowincome individuals who live in border cities of Massachusetts to the population growth rate of low-income individuals who live in non-border cities of Massachusetts. We define various distances to border to identify border cities, specifically, we define a set of indicator variables to categorize cities that are within 0-5 miles, 5-10 miles, 10-15 miles, 15-20 miles, and 20-25 miles from a state border. ${ }^{10}$ The most important property of border analysis models is that any change in a state-level variable that is not different between border and non-border cities will not confound the results. For example, it is reasonable to assume that, say, the extra filing of tax returns in Massachusetts following the MHCR will be the same in border and non-border cities of Massachusetts and therefore will not affect the results of the DID and triple-differences models. Equation (3) shows the DID model for the border analysis:

Pop growth rate ct $=\alpha+\beta_{1}$ After reform $+\beta_{2}$ Border city $5+\beta_{3}$ Border city 10 $+\beta_{4}$ Border city $15+\beta_{5}$ Border city $20+\beta_{6}$ Border city $25+\delta_{1}$ Treatment BDID 5 $+\delta_{2}$ Treatment BDID $10+\delta_{3}$ Treatment BDID15 $+\delta_{4}$ Treatment BDID20 $+\delta_{5}$ Treatment BDID25 $+X \theta+$ City $_{c}+\varepsilon_{c t}$

where the new variables are Border city5 through Border city 25 , which are indicator variables identifying border cities that are within 0-5 miles through 20-25 miles of a state border, and

\footnotetext{
${ }^{10} \mathrm{We}$ are grateful to an anonymous referee for the suggestion that we include multiple variables that allow the impact of the MHCR to vary by distance to the border.
} 
Treatment BDID5 through Treatment BDID25, which are interaction terms between Border city5 through Border city 25 and After reform (with $B$ denoting the border analysis approach and DID again denoting the simple difference-in differences approach). As before, City $y_{c}$ is added to only some specifications as a replacement for Border city 5 through Border city25. Note that these regressions use only data from cities in Massachusetts. As a result, any estimated effect has a potential negative bias because non-border cities may also be affected by this reform.

Similar to the global analysis, we also use a triple-differences model in our border analysis in order to check the robustness of the results, focusing on the cities in Massachusetts and using the high-income population as the comparison group:

$$
\begin{aligned}
& \text { Pop growth rate } \text { gct }=\alpha+\beta_{1} \text { After reform }+\beta_{2} \text { Border city }+\beta_{3} \text { Low income } \\
& \quad+\beta_{4}(\text { After reform } * \text { Border city })+\beta_{5}(\text { After reform } * \text { Low income }) \\
& \quad+\beta_{6}(\text { Border city } * \text { Low income })+\delta_{1} \text { Treatment } B 3 D 5+\delta_{2} \text { Treatment } B 3 D 10 \\
& +\delta_{3} \text { Treatment } B 3 D 15+\delta_{4} \text { Treatment } B 3 D 20+\delta_{5} \text { Treatment } B 3 D 25+X \theta+\text { City }_{c}+\varepsilon_{\text {gct }},(4)
\end{aligned}
$$

where Border city is a vector of dummy variables including the Border city 5 through Border city 25 variables. Treatment B3D5 through Treatment B3D25 are interaction terms composed of three dummy variables: After, Low income, and the corresponding indicator variable in Border city vector (i.e. Border city5 through Border city25). The same qualifier for City $_{c}$ again applies. We also estimate our triple-differences border analysis model using cities in Connecticut and Rhode Island as the third dimension. These (and other) robustness checks are discussed later.

It is important to note that, given our focus on the migration of low-income individuals across the Massachusetts border, the population growth rate is the closest proxy for this migration. In particular, there are no other available data regarding the actual patterns of movement across Massachusetts' borders. This limitation imposes some additional assumptions regarding the similarity of control states (i.e. Connecticut and Rhode Island) to Massachusetts 
with respect to the other variables that could potentially affect the population growth rate of the states included in our analysis. However, these assumptions do not go beyond the usual assumptions of a DID model. They also seem reasonable given the short time-window around the reform that we examine. Even so, we relax those assumptions in the DID models of the later "border analysis" section in which we only compare border to non-border cities of Massachusetts. All of these results are discussed in the following sections.

\section{Data}

We use as our main data set the "population by income group by zip code (PIZ)" data base, which is part of the "Individual Income Tax ZIP Code Data" from the Internal Revenue Service (IRS, 2015). Since 2004, the IRS has aggregated "selected items" from individual tax forms $1040,1040 \mathrm{~A}$, and $1040 \mathrm{EZ}$ received by the IRS between the $1^{\text {st }}$ of January and the $31^{\text {st }}$ of December of the same year (IRS, 2004). Note several aspects of these data. First, these aggregates mainly represent those who file their tax return forms for a specific year, but they also include a very small number of taxpayers who failed to file in previous years and decided to file in the current year (IRS, 2004); given the small number of these taxpayers, their presence is not a concern. Second, these forms do not include the very small number of foreigners who are required to fill out tax forms using forms such as 1040NR or 1040NREZ; the exclusion of these individuals is also not a concern given their small numbers. Third, the IRS data are underrepresentative for low-income individuals who are not required to file tax return forms. However, alternative data bases that have been also used in interstate migration literature such as the American Community Survey (ACS), the Annual Social and Economic Supplements, or the Behavioral Risk Factor Surveillance System data base are not representative at the city level 
generally and for low-income specifically, as required for our border analysis. ${ }^{11}$ We therefore assume that the incidence of under-reporting of low-income individuals is randomly distributed across cities and over time.

Since 2004, the IRS has regularly published PIZ data bases, but before 2004 these publications are limited to some selected years; for example, the closest one before 2004 was published in 2002. For the purpose of our research, we have selected years 2004 through 2007. We exclude years after 2007 to avoid the effects of the 2007-2009 Great Recession. The classification of income groups has been slightly modified over the years. For 2004 and 2005, the IRS used the following classification for the aggregation purposes: "less than $\$ 10 \mathrm{~K}$ ", “between $\$ 10 \mathrm{~K}$ and $\$ 25 \mathrm{~K} "$, "between $\$ 25 \mathrm{~K}$ and $\$ 50 \mathrm{~K} "$, "between $\$ 50 \mathrm{~K}$ and $\$ 75 \mathrm{~K} "$, "between \$75K and \$100K", and finally "more than \$100K". In 2006 and 2007, the last group is divided into "between $\$ 100 \mathrm{~K}$ and $\$ 200 \mathrm{~K}$ " and "more than $\$ 200 \mathrm{~K}$ ". We combine these two groups in 2006 and 2007 to form a "more than $\$ 100 \mathrm{~K}$ " group to have equivalent units across time.

The population in each zip code is determined by the "number of exemptions", as listed in the PIZ data bases. The IRS uses this item as an estimate for the total population in each zip code (IRS, 2004). PIZ data are aggregated to the sub-county level (i.e. towns/cities), as defined by the U.S. Census Bureau for each state. ${ }^{12}$ We aggregate the PIZ data to the city level because, even though individuals pick a specific part of a town or city in which to live, they do not necessarily pick a specific zip code. As a result, it is more accurate to use more aggregation (e.g., to the city level) in analyzing individuals' decisions about where to live. Due to confidentiality concerns, the IRS does not report the population of a specific income group if the number of tax

\footnotetext{
${ }^{11}$ Note that the Behavioral Risk Factor Surveillance System data base has been shown to be representative at the state level (Center for Disease Control, 2015).

${ }^{12}$ Note that these sub-county divisions cover a state map, so that they are collectively exhaustive and mutually exclusive. Even though we refer to these entities as "cities/towns" for simplicity throughout this paper, they are not limited to the urban areas as the term "city/town" may imply.
} 
returns is less than 10. For the estimations presented in this paper, we assign the value zero to any zip code that has a missing value for a specific population group. Our main results remain robust to our imputing other values for missing values and also to our dropping of any city that has a missing value in one of its zip codes for any of the relevant income groups. ${ }^{13}$

We use a combination of geo-analysis and discretion for aggregating the zip code data to the city level. First, using 2010 zip code maps (Census Bureau, 2010) and sub-country divisions (i.e. town/city) maps derived from the Census Bureau (2010), the Connecticut State Data Center (2014), and MassGIS (2014), we identify zip codes that are within a town boundary. Since boundaries of zip codes usually are not exactly within a town map, the centroid of that zip code (or a single, specific location identified as a "dot" on the map) is used to assign a zip code to a town; that is, if the centroid of a zip code is inside a town's boundary, then the zip code is assumed to belong to that town. Some zip code centroids happen to be in the water because the zip code maps sometimes extend to the waters while the town maps do not. These few zip codes are assigned by hand after reviewing the maps. Finally, there are some zip codes that do not have a map, at least in the Census Bureau (2010). These zip codes are examined by hand to decide which town better represents them; in most cases, this was a straightforward task given that these zip codes are mainly alternative codes for zip codes that have maps. It should be noted that, since the boundaries of a few cities do not include a centroid of a zip code, they may appear as if they have been dropped from the data set; however, in fact their population is combined with a neighboring city that shares the zip code (s).

The main variable of interest is the population growth rate of an income group in a specific city. Since the data in this study cover years from 2004 to 2007 , it is only possible to

\footnotetext{
${ }^{13}$ To check the robustness of this decision, we also try different values for the missing population in these zip codes. Our results are robust to how we treat the missing values. These results are not reported, but they are available upon request.
} 
calculate the population growth rate for years 2005 through 2007 . We use years that are completely before and completely after the reform, or 2005 and 2007 . Note that, since the growth rate of population in 2007 is based on the population in 2006 and there is a possibility that the population of low-income groups reacted to the reform in 2006, any estimated effect would be an under-estimation of the true effect.

The control variables are percentage changes in: the unemployment rate, as found in Local Area Unemployment Statistics from Connecticut (2015), Massachusetts (2015), and Rhode Island $(2015)^{14}$; the number of violent crimes (Federal Bureau of Investigation, 2015); per pupil public expenditures (National Center for Education Statistics, 2015); and average wages across industries (County Business Pattern, 2015). ${ }^{15}$

Recall that, for the regressions related to the border analysis, "border" cities are identified based on their proximity to a state's border. The distance of a city's centroid to the closest border is used to determine whether a city is a border city or not, where a city is considered a border city if the centroid of its map is within 25 miles of a Massachusetts border with other states. We use 5 mile increments to categorize border cities and, therefore, we define various dummy variables to identify cities that are within 0-5 miles, 5-10 miles, 10-15 miles, 15-20 miles, and 20-25 miles from the border.

Table 1 provides summary statistics of the main variables of interest for the cities in Massachusetts, Connecticut, and Rhode Island in the year before the reform (2005). Massachusetts is considered the treatment group; Connecticut and Rhode Island (combined) are considered the control group. The choice of these two states as the control states is due to the fact

\footnotetext{
${ }^{14}$ When we include other neighboring states in some robustness checks, we use the Local Area Unemployment (2016) for New Hampshire and the Bureau of Labor Statistics (2016) for New York and Vermont.

${ }^{15} \mathrm{We}$ are grateful to an anonymous referee for the suggestion that we use percentage changes for the control variables.
} 
that, to the best of our knowledge, their subsidized health care programs (e.g., Medicaid) did not change when Massachusetts undertook its reform in 2006. Moreover, choosing these two states as the control group helps us to produce results that are comparable to the previous work on this topic by Schwartz and Sommers (2014). Finally, we use various "parallel-trend" tests to verify that these three states have a similar trend in the population and migration patterns of their lowincome individuals.

Table 1 reveals that the comparison between these states should be done with some care. Prior to the health care reform in Massachusetts, the states have statistically similar growth rates for the low-income populations (MA, -2.1 percent; CT and RI, -2.6 percent), similar percentage changes in the average per pupil expenditure (about 7.1 percent), and similar percentage changes in average wages across all industries (MA, 2.8 percent; CT and RI, 3.6 percent). Even so, the states differ in the growth rates of the high-income population (MA, 11.1 percent; CT and RI, 8.7 percent), the percentage changes in average unemployment rates (MA, -6.5 percent; CT and RI, 0.2 percent), and the percentage changes in average numbers of violent crimes (MA, 31.6 percent; CT and RI, 0.5 percent). For the most part these differences are not economically significant. While we continue to use these states as the control group in the global analysis, in our main border analysis we compare Massachusetts-to-Massachusetts, so that these results are not affected by any potential problem of lack of similarity across states.

Relatedly, it is also important to examine the trends in the population and migration patterns of low-income households, as a test of the "parallel-trend" assumption required in DID estimation; that is, do Massachusetts, Connecticut, and Rhode Island have similar trends in the population and migration patterns of their low-income individuals prior to the health care reform in Massachusetts? Here we rely on data from the IRS (specifically PIZ data) and the ACS, 
available through Ruggles et al. (2015). The IRS data only allow us to look at the change in population of low-income individuals; the ACS data provide the necessary variables to directly compare the in- and out-migration of low-income individuals. These tests follow a similar model in which the percentage change in population of low-income individuals (or the percentage change in the population of low-income individuals who in-migrate to or out-migrate from a state) is regressed on a constant, an indicator variable for Massachusetts, a time trend variable (or a set of time-fixed-effects), and a Massachusetts-specific time trend. The variable of interest is the Massachusetts-specific time trend, which we expect to be statistically insignificant given the data used for these parallel-trend tests are from years prior to 2006. Table 2 reports the results of these parallel-trend tests. Panel A focuses on the population growth rate of low- income individuals. Regardless of the data base (IRS or ACS) and the control variable for the time (timetrend or time-fixed-effects), the Massachusetts-specific time trend is statistically insignificant. Panel B focuses on the ACS data and percentage change of in-migration and out-migration of low- income individuals, and demonstrates that Massachusetts does not display any different trend in the in-migration or out-migration of low-income individuals.

Overall, we are confident that Connecticut and Rhode Island are proper control states for Massachusetts. However, as noted earlier and as discussed later, we also test the robustness of our main global results by including all neighboring states (Connecticut, Rhode Island, New York, New Hampshire, and Vermont). Our results are unaffected.

\section{$\underline{\text { 5. Results and Discussion }}$}

\subsection{Simple DID Calculations}


It is useful to first present the simple DID calculations, for both the global and the border analysis models. Panel A in Table 3 demonstrates the DID calculation for the global analysis, where the average growth rate of low-income individuals in cities of Massachusetts is compared to the rate in Connecticut and Rhode Island following the reform. A simple DID calculation for the global analysis shows that the potential effect would be an additional 3.02 percentage point population growth rate for the low-income individuals in Massachusetts following the reform, although this difference is not statistically significant. Similarly, Panel B in Table 3 demonstrates a simple DID calculation for the border analysis, in which the average population growth rate of low-income individuals in border cities of Massachusetts (i.e. cities within 10 miles of a border) is compared to non-border cities of Massachusetts. This DID calculation shows that the population growth rate of low-income individuals in cities within 10 miles of border in Massachusetts experienced an extra 13.56 percentage point following the reform, a difference that is statistically significant at the 1 percent significance level and very much robust to the use of alternative models.

\subsection{Global Analysis Models}

We next present our global analysis models, in which we estimate the determinants of the population growth rate of low-income individuals in all towns in Massachusetts relative to Connecticut and Rhode Island. We estimate both difference-in-differences (DID) and tripledifferences models of equations (1) and (2).

The first set of results is for equation (1), and is presented in Table 4. Beginning with a simple DID model without controlling for any other covariates, the population of low-income individuals in Massachusetts experienced an extra 3.02 percentage point growth rate following the reform comparing to the same income group in Connecticut and Rhode Island (column 1). 
Adding other control variables increases the observed effect to an extra 4.64 percentage point population growth (column 2), statistically significant at the 5 percent level. Adding city fixed effects without any control variables reduces this impact to 3.00 percentage points (column 3). Also, controlling for other covariates does not change the results significantly (column 4); the effect is still small (4.02 percentage points) and statistically marginally significant. However, the statistical significance of our preferred model (column 4) is an artifact of the treatment of the zip codes with missing values. If instead of imputing zero for these missing values we drop the cities to which these zip codes correspond, then the statistical significance of the main parameter of interest vanishes. Therefore, we prefer to be conservative and conclude that there is no robust global effect for the health care reform in Massachusetts. Overall, the models do an acceptable job in explaining the variation in the data, generally around three-fourths of the variation in the population growth rate of low-income individuals in these three states.

As pointed out in the methods section, unobservable variables that may have changed in one of these states at the time of reform may bias the results in an unknown way. Assuming these variables affect all income groups similarly, a triple-differences model that uses another income group as the third dimension can reduce this potential bias. Since the MHCR does not provide any subsidy for high-income individuals, using this income group helps to account for this potential bias. Equation (2) is the triple-differences model that we use.

The results for the triple-differences models in Table 5 show that there is no robust global effect of the MHCR on the population growth rate of low-income individuals in Massachusetts. Despite the fact that our main parameter of interest in the preferred model is marginally statistically significant, this finding is not robust to the change of treatment of the missing values in the IRS zip code data base. The low-income population generally grows at a lower rate 
relative to the high-income population before the reform, but after year 2006 the population growth rate of low-income individuals increases dramatically in all three states relative to prereform, by about 51 percentage points. ${ }^{16}$

Given that all of these global analysis models fail to identify any robust effect for the MHCR, we conclude that the reform did not have a global effect that is large enough to be identified. However, this lack of finding from the global analysis models does not rule out the existence of a more localized effect on the cities that are close to the border of Massachusetts. Low-income individuals who live in a border city of a neighboring state may simply move a few miles to become a resident of Massachusetts and benefit from the reform. The next subsection presents the results for the border analysis models.

\subsection{Border Analysis Models}

In the DID models for our border analysis, the population growth rates of low-income individuals in border versus non-border cities of Massachusetts are compared to each other following the reform, where we identify border towns in 5 mile increments up to 25 miles from the state border.

As shown in Table 6, border cities of Massachusetts experienced an extra population growth for their low-income individuals following the reform. In our preferred specification (column 4), this extra population growth is estimated to be 18.47 and 10.72 percentage points for cities that are within 0-5 miles and 5-10 miles of Massachusetts' borders, respectively. Importantly, the effect is not statistically significant for cities that are beyond 10 miles of the

\footnotetext{
${ }^{16}$ Note that the population growth rate of low-income individuals increased dramatically (about 49 percentage points) in Massachusetts, Connecticut, and Rhode Island after year 2006. We have discussed this issue with IRS researchers, and they confirm that our data are correct. Even so, we used for each state the IRS-aggregated number of exemptions for individuals whose income is less than $\$ 10 \mathrm{~K}$, and we found the growth rate in 2007 to be 57.64 percent, 49.71 percent, and 48.42 percent for Massachusetts, Connecticut and Rhode Island, respectively. However, the total number of exemptions (i.e. population) in these states has a much lower growth rate: 6.53 percent (MA), 5.42 percent $(\mathrm{CT})$, and 6.31 percent (RI), respectively.
} 
border. Overall, the population growth rate of low-income individuals increased dramatically (about 48 percentage points) in all cities of Massachusetts following the reform. Our preferred specification in column 4 explains about 73 percent variation in the data.

We also utilize triple-differences border analysis models, based on equation (4). For this purpose, we focus on cities in Massachusetts, and we use the high-income population as the third dimension. These results are presented in Table 7. Our preferred specification (column 4) shows an additional $22.84,14.88,8.17$, and 6.97 percentage points extra population growth rate for low-income individuals in the border cities of Massachusetts that are located within 0-5, 5-10, 10-15, and 15-20 miles from this state's border, respectively, following the reform. These estimates are largely the same (if slightly larger) than the DID model estimates.

To further test the robustness of these triple-differences estimates, we compare the population growth rate of low-income individuals in border towns of Massachusetts to nonborder cities of this state, but we now use the same difference in Connecticut/Rhode Island to rule out any potential non-reform-related increase in the population growth rate of low-income individuals in the border cities of Massachusetts (Table 8). In our preferred specification (column 4), the reform effect is estimated to be about 24.97, 20.60, and 17.67 percentage points extra population growth rate for the low-income population of border cities of Massachusetts who live in cities within 0-5, 5-10, and 10-15 miles from the Massachusetts border, respectively. We use these estimates as our upper bound estimate for the border effect, given the potential positive bias of this triple-differences model.

Overall, the results across the different border analysis DID and triple-differences models show that at the 95 percent confidence level, the population of low-income individuals who live in cities within 0-5 miles of the Massachusetts border experienced between 18.47 and 24.97 
percentage points extra growth rate following the reform. Once again, the impact of the reform decreases for cities farther from the border. For example, the effects for the cities that are located between 5-10 and 10-15 miles of the Massachusetts border are an additional 10.72 to 20.60 and 5.12 to 17.67 percentage points, respectively. We do not observe any robust reform effect on the cities that are located beyond 15 miles distance from the Massachusetts border.

Figure 1 provides a map of the Massachusetts cities with the estimates effects from the passage of the MHCR translated into the number of additional low-income residents in each city. For cities that are within 0-5 miles of the border, the MHCR increased the number of lowincome residents by an additional 203-275 new residents. For cities that are located in 5-10 and 10-15 miles distance from border, the effect is 151-290 and 0-129 new low-income residents, respectively. Given these values, the total number of new low-income residents in all of the border towns is about 21 thousand to 40 thousand.

\subsection{Additional Robustness Checks}

To further test the robustness of these results, we conduct various additional tests. First, we re-estimate the last triple-differences model that relies on the neighboring states of Massachusetts, but we now include all neighboring states instead of only Connecticut and Rhode Island. These results are reported in Table 9, and they are very similar to those reported in Table 8. Based on the preferred specification (Table 9, column 4), the Massachusetts Health Care Reform caused an additional growth rate of 19.89 percentage points for the low-income population of cities that are located within 0-5 miles of this state's border. As with our previous estimates, the size of the effect decreases for cities farther from the border. The reform has no effect on cities that are beyond 20 miles of the Massachusetts border. 
Second, we use pseudo- or placebo-regressions that evaluate the effect of reform on the population growth rate of high-income individuals (or those making more than $\$ 100 \mathrm{~K}$ a year) living in the border cities of Massachusetts using cities in all neighboring states as the control group. Given that high-income individuals did not receive any subsidies from the MHCR, we would not expect the reform to have any impact on their growth rates. The results of this placebo test are reported in Table 10. As expected, we do not observe any statistically significant effect of reform on the population growth rate of high income residents of border cities of Massachusetts regardless of how close or far they are from the border.

Third, we conduct a series of sensitivity analysis with regard to the treatment of the missing values in the population-by-zip-code data base as well as the control variables. For example, in our previous estimations we imputed the value zero whenever the size of a population group is missing in a zip code. However, the value of these missing values could be anything between zero and 9, given IRS practices. Therefore, we reproduced all of our results by imputing the value 5 and then the value 9 wherever there was a missing value in our populationby-zip-code data. We also reproduced our results by dropping any city that has a zip code with a missing value in any years included in this analysis. Finally, we imputed the value zero for any cities with missing values for control variables, and we also included a set of indicator variables (i.e. "flags") in regressions to identify these observations with a missing value for a control variable. We repeated all of our estimations by dropping cities with missing values for control variables. All of our main conclusions are unaffected by each of these changes. These results are not reported, here but they are available upon request.

\section{Conclusions}


In this study we examine the effect of Massachusetts Health Care reform of 2006 on interstate migration to Massachusetts, in order to test the "welfare magnet" theory. Using difference-in-differences and triple-differences models, we first look at the global effect of this reform on all cities in Massachusetts. Similar to recent work by Schwartz and Sommers (2014), we find that the population of low-income individuals in Massachusetts did not experience an extra growth rate following the reform. However, when we narrow our analysis to the border cities of Massachusetts, we find that the reform increased the population growth rate of lowincome individuals in border cities of this state, but we also find that this effect disappears quickly for cities farther from the state border. We estimate about 21 thousand to 40 thousand additional low-income individuals moved to Massachusetts following the reform.

We are able to calculate an approximate estimate of the additional annual budgetary burden of these new low-income residents. The average cost of the MHCR reform in 2007 was $\$ 649$ per person for each additional individual not insured through private employers. ${ }^{17}$ The total burden of these new residents is therefore about $\$ 14$ to $\$ 26$ million. Given the total cost of the MHCR reform in 2007 (or $\$ 1.3$ billion), the additional annual cost of these new residents is between 1 to 2 percent of the total cost for the state.

These results suggest that states that have decided to expand their Medicaid program - or those that are considering doing so - should recognize that providing more generous coverage will likely lead to an increase in their low-income population. Even so, our results also suggest that states should not be overly worried about the financial burden of a huge influx of lowincome households to their states. The benefits of health care expansion attract some low-income

\footnotetext{
${ }^{17}$ This estimate is calculated using the following data. First, the estimated population of Massachusetts in 2007 was 6.432 million (Census Bureau, 2012) of which about 98 percent were insured. Second, of those who were insured, about 32 percent were not insured by private employers (Long et al., 2008). Third, the total cost of the reform in 2007 was $\$ 1.3$ billion (Raymond, 2012).
} 
individuals, but the magnitude of the inflow seems manageable. Further, if all states expand their coverage simultaneously, then the relative advantage of one state over another diminishes considerably. Even though expansion of health care - or indeed, of any low-income transfers creates incentives for mobility, it is still the case that the effects of expansion depend significantly on what all states decide to do, and not simply on what a single state chooses.

\section{References}

American Community Survey, 2015. Race: (2005 and 2007) American Community Survey- 1Year Estimates. Washington, D.C.: American Community Survey. Available at: http://factfinder.census.gov/faces/nav/jsf/pages/searchresults.xhtml?refresh=t .

Allard, Scott W., \& Danziger, Sheldon, 2000. Welfare magnets: Myth or reality? The Journal of Politics, 62 (2), 350-368.

Anjomani, Ardeshir, 2002. Regional growth and interstate migration. Socio-Economic Planning Sciences, 36 (4), 239-265.

ASPE (Office of the Assistant Secretary for Planning and Evaluation), 2005. The $2005 \mathrm{HHS}$ Poverty Guidelines. U.S. Department of Health and Human Services. Washington, D.C. Available at: http://aspe.hhs.gov/2005-hhs-poverty-guidelines.

Bailey, Michael A., \& Rom, Mark Carl, 2004. A wider race? Interstate competition across health and welfare programs. Journal of Politics, 66 (2), 326-347.

Bayer, Christian, \& Juessen, Falko, 2012. On the dynamics of interstate migration: Migration costs and self-selection. Review of Economic Dynamics, 15 (3), 377-401.

Beeson, Patricia E., DeJong, David N., \& Troesken, Werner, 2001. Population growth in US counties, 1840-1990. Regional Science and Urban Economics, 31 (6), 669-699.

Blendon, Robert J., Buhr, Tami, Sussman, Tara, \& Benson, John M., 2008. Massachusetts health reform: A public perspective from debate through implementation. Health Affairs, 27 (6), w556-w565.

Bovenberg, A. Lans, \& Jacobs, Bas, 2005. Redistribution and education subsidies are Siamese twins. Journal of Public Economics, 89 (11-12), 2005-2035.

Brueckner, Jan K., 1999. Welfare reform and the race to the bottom: Theory and evidence. Southern Economic Journal, 66 (2), 505-525.

Bureau of Labor Statistics, 2016. The Local Area Unemployment Statistics. Washington, D.C.: Bureau of Labor Statistics. Available at: http://www.bls.gov/lau/ .

County Business Pattern, 2006. County Business Patterns: Geography Area Series: County Business Patterns by Employment Size Class. Available at: http://factfinder.census.gov/faces/nav/jsf/pages/searchresults.xhtml?refresh=t.

Center for Disease Control and Prevention, 2005. Behavioral Risk Factor Surveillance System, Surveillance Resource Center. Atlanta, GA: Center for Disease Control and Prevention. Available at: http://www.cdc.gov/surveillancepractice/reports/brfss/brfss_faqs.html .

Cebula, Richard J., \& Alexander, Gigi M., 2006. Determinants of net interstate migration, 20002004. Journal of Regional Analysis and Policy, 36 (2), 116-123. 
Cebula, Richard J., \& Clark, J. R., 2013. An extension of the Tiebout hypothesis of voting with one's feet: The Medicaid magnet hypothesis. Applied Economics, 45 (32), 4575-4583.

Census Bureau, Geography Division, 2010. 2010 TIGER/Line ${ }^{\circledR}$ Shapefiles. Washington, D.C.: U.S. Census Bureau, Geography Division. Available at: https://www.census.gov/cgibin/geo/shapefiles2010/main.

Census Bureau, Population Division, 2012. Intercensal Estimates of the Resident Population by Sex and Age for Massachusetts: April 1, 2000 to July 1, 2010 (ST-ESTO0INT-02-25), Table 2. Washington, D.C.: U.S. Census Bureau, Population Division.

Courtemanche, Charles J., \& Zapata, Daniela, 2014. Does universal coverage improve health? The Massachusetts experience. Journal of Policy Analysis and Management, 33 (1), 36-69.

Conway, Karen Smith, \& Houtenville, Andrew J., 2003. Out with the old, in with the old: A closer look at younger versus older elderly migration. Social Science Quarterly, 84 (2), 309328.

Connecticut State Data Center, 2014. Hartford, CN. Available at: http://ctsdc.uconn.edu/connecticut_census_data/.

De Jong, Gordon F., Graefe, Deborah Roempke, \& St. Pierre, Tanja, 2005. Welfare reform and interstate migration of poor families. Demography, 42 (3), 469-496.

Eeckhout, Jan, 2004. Gibrat's law for (all) cities. The American Economic Review, 94 (5), 14291451.

Families USA, 2017. A 50-state look at Medicaid expansion. Washington, D.C. Available at: http://familiesusa.org/product/50-state-look-medicaid-expansion.

Federal Bureau of Investigation, 2015. Crime - Local Level Data with One Variable. Washington, D.C.: Federal Bureau of Investigation. Available at: http://www.ucrdatatool.gov/Search/Crime/Local/TrendsInOneVar.cfm.

Foote, Andrew, 2016. The effects of negative house price changes on migration: Evidence across US housing downturns. Regional Science and Urban Economics, 60, 292-299.

Gabel, Jon R., Whitmore, Heidi, \& Pickreign, Jeremy, 2008. Report from Massachusetts: Employers largely support health care reform, and few signs of crowd-out appear. Health Affairs, 27 (1), w13-w23.

Garthwaite, Craig, Gross, Tal, \& Notowidigdo, Matthew J., 2014. Public health insurance, labor supply, and employment lock. The Quarterly Journal of Economics, 129 (2), 653-696.

Greenhalgh-Stanley, Nadia, \& Rohlin, Shawn, 2014. Mandate-based health care reform and business activity: Evidence from Massachusetts. Kent State University Department of Economics Working Paper. Kent, $\mathrm{OH}$.

Giulietti, Corrado, \& Wahba, Jackline, 2012. Welfare migration. IZA Discussion Paper No. 6450. Bonn, Germany: Institute for the Study of Labor (IZA).

Gurak, Douglas T., \& Kritz, Mary M., 2000. The interstate migration of US immigrants: Individual and contextual determinants. Social Forces, 78 (3), 1017-1039.

Headey, Bruce, Goodin, Robert E., Muffels, Ruud, \& Dirven, Henk-Jan, 2000. Is there a tradeoff between economic efficiency and a generous welfare state? A comparison of best cases of "The Three Worlds of Welfare Capitalism". Social Indicators Research, 50 (2), 115-157.

Holahan, John, \& Blumberg, Linda, 2006. Massachusetts health care reform: A look at the issues. Health Affairs, 25 (6), w432-w443.

Internal Revenue Service, 2004. Individual Income Tax Statistics - ZIP Code Data (SOI): Information Files for Year 2004. Washington, D.C.: Internal Revenue Service. Available at: 
http://www.irs.gov/uac/SOI-Tax-Stats-Individual-Income-Tax-Statistics-ZIP-Code-Data(SOI) .

Internal Revenue Service, 2015. Individual Income Tax Statistics - ZIP Code Data (SOI).

Washington, D.C.: Internal Revenue Service. Available at: http://www.irs.gov/uac/SOI-TaxStats-Individual-Income-Tax-Statistics-ZIP-Code-Data-(SOI).

Kaestner, Robert, Kaushal, Neeraj, \& Van Ryzin, Gregg, 2003. Migration consequences of welfare reform. Journal of Urban Economics, 53 (3), 357-376.

Kenney, Genevieve M., Long, Sharon K., \& Luque, Adela, 2010. Health reform in

Massachusetts cut the uninsurance rate among children in half. Health Affairs, 29 (6), 12421247.

Kolstad, Jonathan T., \& Kowalski, Amanda E., 2012. The impact of health care reform on hospital and preventive care: Evidence from Massachusetts. Journal of Public Economics, 96 (11), 909-929.

Local Area Unemployment Statistics CT, 2015. Hartford, CT: Connecticut Department of Labor. Available at: http://www1.ctdol.state.ct.us/lmi/laus/laustown.asp.

Local Area Unemployment Statistics MA, 2015. Boston, MA: Executive Office of Labor and Workforce Development in Massachusetts. Available at: http://lmi2.detma.org/lmi/lmi_lur_a.asp.

Local Area Unemployment Statistics NH, 2016. Concord, NH: Economic and Labor Market Information Bureau of New Hampshire. Available at: http://www.nhes.nh.gov/elmi/statistics/candt-arch.htm.

Local Area Unemployment Statistics RI, 2015. Providence, RI: Rhode Island Department of Labor and Training. Available at: http://www.dlt.ri.gov/lmi/laus.htm.

Long, Sharon K., 2008. On the road to universal coverage: Impacts of reform in Massachusetts at one year. Health Affairs, 27 (4), w270-w284.

Long, Sharon K., Cook, Allison, \& Stockley, Karen, 2008. Health Insurance Coverage in Massachusetts: Estimates from the 2008 Massachusetts Health Insurance Survey. Boston, MA: Commonwealth of Massachusetts, Division of Health Care Finance and Policy.

Long, Sharon K., Stockley, Karen, \& Dahlen, Heather, 2012. Massachusetts health reforms: Uninsurance remains low, self-reported health status improves as state prepares to tackle costs. Health Affairs, 31 (2), 444-451.

MassGIS, 2012. Office of Geographic Information (MassGIS), Commonwealth of Massachusetts, MassIT. Boston, MA. Available at: http://www.mass.gov/anf/research-andtech/it-serv-and-support/application-serv/office-of-geographic-informationmassgis/datalayers/layerlist.html.

McKinnish, Terra, 2005. Importing the poor: Welfare magnetism and cross-border welfare migration. Journal of Human Resources, 40 (1), 57-76.

McKinnish, Terra, 2007. Welfare-induced migration at state borders: New evidence from microdata. Journal of Public Economics, 91 (3-4), 437-450.

McKinnish, Terra, 2017. Cross-state differences in the minimum wage and out-of-state commuting for low-wage workers. Regional Science and Urban Economics, 64, 137-147.

McDonough, John E., Rosman, Brian, Phelps, Fawn, \& Shannon, Melissa, 2006. The third wave of Massachusetts health care access reform. Health Affairs, 25 (6), w420-w431.

McDonough, John E., Rosman, Brian, Butt, Mehreen, Tucker, Lindsey, \& Howe, Lisa Kaplan, 2008. Massachusetts health reform implementation: Major progress and future challenges. Health Affairs, 27 (4), w285-w297. 
McHugh, Kevin E., \& Gober, Patricia, 1992. Short-term dynamics of the US interstate migration system, 1980-1988. Growth and Change, 23 (4), 428-445.

Mehren, Elizabeth, 2006. Massachusetts opens healthcare umbrella. The Los Angeles Times, 13 April 2006. Available at: http://articles.latimes.com/2006/apr/13/nation/na-health13.

Miller, Sarah, 2012a. The effect of insurance on emergency room visits: An analysis of the 2006 Massachusetts health reform. Journal of Public Economics, 96 (11), 893-908.

Miller, Sarah, 2012b. The impact of the Massachusetts health care reform on health care use among children. The American Economic Review, 102 (3), 502-507.

Miller, Sarah, 2012c. The effect of the Massachusetts reform on health care utilization. INQUIRY: The Journal of Health Care Organization, Provision, and Financing, 49 (4), 317-326.

Modestino, Alicia Sasser, \& Dennett, Julia, 2013. Are American homeowners locked into their houses? The impact of housing market conditions on state-to-state migration. Regional Science and Urban Economics, 43 (2), 322-337.

Nannestad, Peter, 2007. Immigration and welfare states: A survey of 15 years of research. European Journal of Political Economy, 23 (2), 512-532.

National Center for Education Statistics, 2015. U.S. Department of Education. Washington, D.C.: U.S. Department of Education. Available at: http://nces.ed.gov/ccd/elsi/tableGenerator.aspx.

Raymond, Alan G., 2012. Massachusetts Health Reform Spending, 2006-2011: An Update on the "Budget Buster" Myth. Boston, MA: Massachusetts Taxpayers Foundation.

Ruggles, Steven, Genadek, Katie, Goeken, Ronald, Grover, Josiah, \& Sobek, Matthew, 2015. Integrated Public Use Microdata Series: Version 6.0 [Machine-readable database]. Minneapolis, MN: University of Minnesota. Available at: https://usa.ipums.org/usa/.

Sasser, Alicia C. 2010. Voting with their feet: Relative economic conditions and state migration patterns. Regional Science and Urban Economics, 40 (2), 122-135.

Schwartz, Aaron L., \& Sommers, Benjamin D., 2014. Moving for Medicaid? Recent eligibility expansions did not induce migration from other states. Health Affairs, 33 (1), 88-94.

Shindul-Rothschild, Judith, \& Gregas, Matt, 2013. Patient turnover and nursing employment in Massachusetts hospitals before and after health insurance reform: Implications for the Patient Protection and Affordable Care Act. Policy, Politics, \& Nursing Practice, 14 (3-4), 151-162.

Smulowitz, Peter. B., Lipton, Robert, Wharam, J. Frank, Adelman, Leon, Weiner, Scott G., Burke, Laura, Baugh, Christopher W. Schuur, Jeremiah D., Liu, Shan W., McGrath, Meghan E., Liu, Bella, Sayah, Assad, Burke, Mary C., Pope, J. Hector, \& Landon, Bruce E., 2011. Emergency department utilization after the implementation of Massachusetts health reform. Annals of Emergency Medicine, 58 (3), 225-234.

Sommers, Benjamin D., Long, Sharon K., \& Baicker, Katherine, 2014. Changes in mortality after Massachusetts Health Care Reform: A quasi-experimental study. Annals of Internal Medicine, 160 (9), 585-593.

Thompson, Mark A., Huerta, Timothy R., \& Ford, Eric W., 2012. Mandatory insurance coverage and hospital productivity in Massachusetts: Bending the curve? Health Care Management Review, 37 (4), 294-300.

Walker, James R., 1994. Migration among low-income households: Helping the witch doctors reach consensus. Institute for Research on Poverty Working Paper. Madison, WI: University of Wisconsin-Madison. 
Yang, Joshua S., \& Wallace, Steven P., 2007. Expansion of health insurance in California unlikely to act as magnet for undocumented immigration. UCLA Center for Health Policy Research. Los Angeles, LA: UCLA.

Zhu, Jane, Brawarsky, Phyllis, Lipsitz, Stuart, Huskamp, Haiden, \& Haas, Jennifer S., 2010. Massachusetts health reform and disparities in coverage, access and health status. Journal of General Internal Medicine, 25 (12), 1356-1362. 
Figure 1: The Effect of the MHCR on the Population of Low-income Residents of Cities in Massachusetts Based on the Distance to the Border

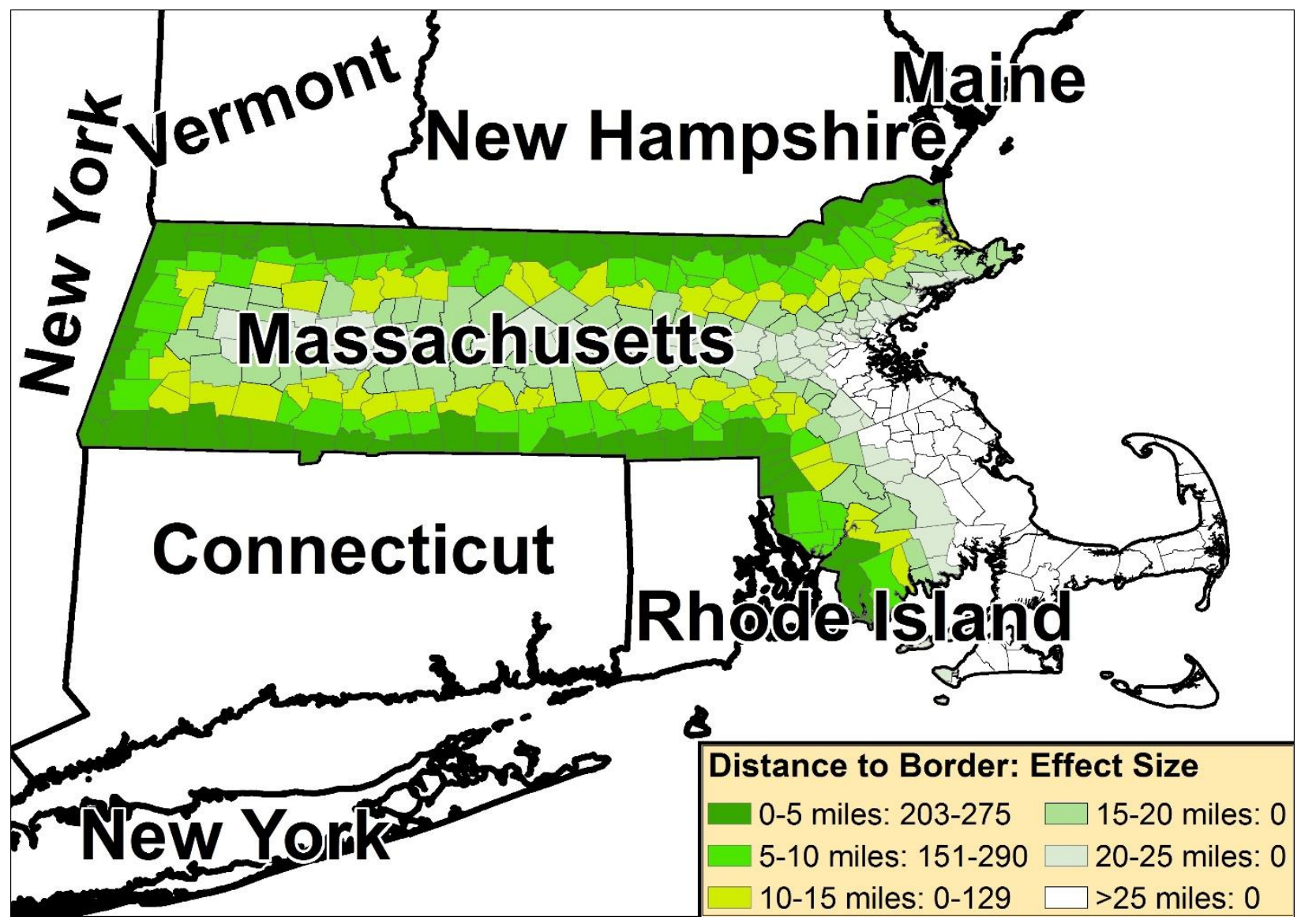

Note: The effect size is presented in terms of upper and lower bounds. These values represent the average number of additional low-income residents in a city due to the passage of MHCR based on parameter estimates that are statistically significant at the 95 percent confidence level. 
Table 1: Summary Statistics for Main Variables in Massachusetts versus Connecticut and Rhode Island (combined)

\begin{tabular}{|c|c|c|c|c|c|}
\hline Variable & Year & $\begin{array}{c}\text { Average Across } \\
\text { Cities or Counties }\end{array}$ & Massachusetts & $\begin{array}{l}\text { Connecticut and } \\
\text { Rhode Island } \\
\end{array}$ & Difference \\
\hline $\begin{array}{l}\text { Average growth rate of low- } \\
\text { income population (Annual } \\
\text { income }<\$ 10 \mathrm{~K} \text { ) }\end{array}$ & 2005 & Cities & $\begin{array}{c}-0.0212 \\
(0.0061) \\
{[337]}\end{array}$ & $\begin{array}{c}-0.0255 \\
(0.0052) \\
{[205]}\end{array}$ & $\begin{array}{c}0.0004 \\
(0.0089) \\
{[542]}\end{array}$ \\
\hline $\begin{array}{l}\text { Average growth rate of high- } \\
\text { income population (Annual } \\
\text { income }>\$ 100 \mathrm{~K} \text { ) }\end{array}$ & 2005 & Cities & $\begin{array}{c}0.1106 \\
(0.0070) \\
{[336]}\end{array}$ & $\begin{array}{c}0.0866 \\
(0.0040) \\
{[205]}\end{array}$ & $\begin{array}{c}0.0240 * * * \\
(0.0095) \\
{[541]}\end{array}$ \\
\hline $\begin{array}{l}\text { Percentage change in } \\
\text { average unemployment rate }\end{array}$ & 2004-05 & Cities & $\begin{array}{c}-0.0651 \\
(0.0057) \\
{[338]}\end{array}$ & $\begin{array}{c}0.0021 \\
(0.0044) \\
{[205]}\end{array}$ & $\begin{array}{c}-0.0671 * * * \\
(.0080) \\
{[543]}\end{array}$ \\
\hline $\begin{array}{l}\text { Percentage change in } \\
\text { average number of violent } \\
\text { crimes }\end{array}$ & 2004-05 & Counties & $\begin{array}{c}0.3156 \\
(0.3034) \\
{[13]}\end{array}$ & $\begin{array}{c}0.0048 \\
(0.0538) \\
{[13]}\end{array}$ & $\begin{array}{c}0.3108 \\
(0.3082) \\
{[26]}\end{array}$ \\
\hline $\begin{array}{l}\text { Percentage change in } \\
\text { average per pupil public } \\
\text { expenditure }\end{array}$ & 2004-05 & Counties & $\begin{array}{c}0.0706 \\
(0.0090) \\
{[14]}\end{array}$ & $\begin{array}{c}0.0713 \\
(0.0051) \\
{[13]}\end{array}$ & $\begin{array}{c}-0.0007 \\
(0.0105) \\
{[27]}\end{array}$ \\
\hline $\begin{array}{l}\text { Percentage change in } \\
\text { average wage across all } \\
\text { industries }\end{array}$ & 2004-05 & Counties & $\begin{array}{c}0.0278 \\
(0.0128) \\
{[14]}\end{array}$ & $\begin{array}{c}0.0361 \\
(0.0054) \\
{[13]}\end{array}$ & $\begin{array}{c}0.0083 \\
(0.0143) \\
{[27]}\end{array}$ \\
\hline
\end{tabular}

Note: Standard errors are in parentheses, and the number of cities/counties is in brackets. The total number of cities includes those with missing values for any of these variables. Significance levels: $*=p<0.10, * *=p<0.05, * * *=$ $\mathrm{p}<0.01$. 
Table 2: Parallel-trend Tests Comparing the Low-income Populations and Migration Patterns in Massachusetts to Connecticut and Rhode Island (combined)

Panel A. Low-income Population

\begin{tabular}{l|c|c|c|c}
\hline $\begin{array}{c}\text { Dependent Variable: } \\
\text { Population Growth Rate }\end{array}$ & \multicolumn{2}{|c|}{ IRS Data } & \multicolumn{2}{c}{ ACS Data } \\
\hline MA * Year & 0.0181 & 0.0181 & 0.0197 & 0.0197 \\
& $(0.1127)$ & $(0.0151)$ & $(0.0425)$ & $(0.0500)$ \\
\hline Time Trend? & Yes & No & Yes & No \\
Year FE? & No & Yes & No & Yes \\
R-Squared & 0.12 & 0.99 & 0.10 & 0.25 \\
F(all covariates) & 0.49 & $101.06^{* * *}$ & 0.61 & 0.65 \\
\hline \hline
\end{tabular}

Panel B. Low-income In- and Out-migration

\begin{tabular}{l|c|c|c|c}
\hline \multirow{2}{*}{$\begin{array}{c}\text { Dependent Variable: } \\
\text { Population Growth Rate }\end{array}$} & \multicolumn{4}{c}{ ACS Data } \\
\cline { 2 - 5 } MA * Year & \multicolumn{2}{|c}{ In-migration } & \multicolumn{2}{c}{ Out-migration } \\
\hline Time Trend? & -0.0324 & -0.0956 & -0.1255 & -0.2360 \\
Year FE? & Yes & No & Yes & No \\
R-Squared & No & Yes & No & Yes \\
F(all covariates) & 0.08 & 0.39 & 0.07 & 0.22 \\
\hline \hline
\end{tabular}

Note: Robust standard errors are in parentheses. All models have a constant term and an indicator variable for the state of Massachusetts. IRS and ACS are both at the state level. IRS data cover years 1998, 2001, 2002, 2004, and 2005. ACS data cover years 2000 through 2005. Significance levels: $*=p<0.10, * *=p<0.05, * * *=p<0.01$.

Table 3: Simple Difference-in-differences Results for Population Growth Rates of Lowincome Individuals

Panel A. Cities of Massachusetts Versus Cities of Connecticut and Rhode Island (combined)

\begin{tabular}{l|c|c|c}
\hline Variable: Population Growth Rate & Pre-reform & Post-reform & Difference \\
\hline Massachusetts & -0.0212 & 0.5336 & $0.5548^{* * *}$ \\
& $(0.0061)$ & $(0.0126)$ & $(0.0140)$ \\
Connecticut and Rhode Island & -0.0255 & 0.4991 & $0.5246^{* * *}$ \\
& $(0.0052)$ & $(0.0119)$ & $(0.0130)$ \\
\hline \multicolumn{2}{l|}{} & & $\mathbf{0 . 0 3 0 2}$ \\
& & $\mathbf{( 0 . 0 2 0 7 )}$ \\
\hline \hline
\end{tabular}

Panel B. Border Versus Non-border Cities of Massachusetts

\begin{tabular}{l|c|c|c}
\hline Variable: Population Growth Rate & Pre-reform & Post-reform & Difference \\
\hline \multirow{2}{*}{ Border cities (10miles) } & -0.0210 & 0.6215 & $0.6425^{* * *}$ \\
& $(0.0070)$ & $(0.0226)$ & $(0.0237)$ \\
\multirow{2}{*}{ Non-border cities } & -0.0213 & 0.4856 & $0.5069 * * *$ \\
& $(0.0087)$ & $(0.0141)$ & $(0.0166)$ \\
\hline \multirow{2}{*}{ Difference-in-Differences } & & $\mathbf{0 . 1 3 5 6 * * *}$ \\
\hline
\end{tabular}

Note: Standard errors are in parentheses. Significance levels: ${ }^{*}=\mathrm{p}<0.10,{ }^{* *}=\mathrm{p}<0.05,{ }^{* * *}=\mathrm{p}<0.01$. 
Table 4: Regression Results of Global Analysis DID models: Comparing Individuals Who Made Less Than \$10K in Massachusetts to Those in Connecticut and Rhode Island (combined)

\begin{tabular}{|c|c|c|c|c|}
\hline $\begin{array}{c}\text { Dependent Variable: } \\
\text { Population Growth Rate }\end{array}$ & $\begin{array}{c}\text { (1) } \\
\text { OLS }\end{array}$ & $\begin{array}{c}(2) \\
\text { OLS }\end{array}$ & $\begin{array}{c}\text { (3) } \\
\text { Fixed Effects } \\
\text { (City) }\end{array}$ & $\begin{array}{c}\text { (4) } \\
\text { Fixed Effects } \\
\text { (City) }\end{array}$ \\
\hline $\begin{array}{l}\text { MA } * \text { After reform } \\
\quad(\text { Treatment GDID) }\end{array}$ & $\begin{array}{c}0.0302 \\
(0.0191)\end{array}$ & $\begin{array}{l}0.0464 * * \\
(0.0211)\end{array}$ & $\begin{array}{c}0.0300 \\
(0.0194)\end{array}$ & $\begin{array}{l}0.0402 * \\
(0.0227)\end{array}$ \\
\hline After reform (Year>2006) & $\begin{array}{l}0.5246^{* * * *} \\
(0.0130)\end{array}$ & $\begin{array}{l}0.5130 * * * \\
(0.0135)\end{array}$ & $\begin{array}{l}0.5246 * * * \\
(0.0132)\end{array}$ & $\begin{array}{l}0.5113 * * * \\
(0.0141)\end{array}$ \\
\hline MA & $\begin{array}{c}0.0043 \\
(0.0080) \\
\end{array}$ & $\begin{array}{l}0.0159 * \\
(0.0096)\end{array}$ & & \\
\hline Control variables? & No & Yes & No & Yes \\
\hline $\mathrm{N}$ & 1084 & 1084 & 1084 & 1084 \\
\hline Adjusted R-Squared & 0.73 & 0.74 & 0.73 & 0.74 \\
\hline $\mathrm{F}($ all covariates $)$ & $1068.54 * * *$ & $426.82 * * *$ & $1552.81 * * *$ & $484.93 * * *$ \\
\hline $\begin{array}{l}\text { Mean dependent variable } \\
\text { [Standard deviation] }\end{array}$ & $\begin{array}{c}0.2489 \\
{[0.3180]}\end{array}$ & $\begin{array}{c}0.2489 \\
{[0.3180]}\end{array}$ & $\begin{array}{c}0.2489 \\
{[0.3180]}\end{array}$ & $\begin{array}{c}0.2489 \\
{[0.3180]}\end{array}$ \\
\hline
\end{tabular}

Note: Robust standard errors are in parentheses, and all models have a constant term. Control variables include: the percentage change in the unemployment rate in a city, the number of violent crimes in a county, per pupil public expenditures in a county, average wages across industries in a county, and indicator variables (i.e. "flag" variables) for cities with missing values for each of these control variables. Cities with missing values for any of the control variables receive the value zero for that variable. The data cover one year before the reform (2005) and one year after the reform (2007). Significance levels: $*=p<0.10, * *=p<0.05, * * *=p<0.01$. 
Table 5: Regression Results of Global Analysis Triple-differences Models: Comparing Individuals Who Made Less Than $\$ 10 \mathrm{~K}$ in Massachusetts to Those in Connecticut and Rhode Island (combined) and Using Those Who Made More Than $\$ 100 K$ as the Third Dimension

\begin{tabular}{|c|c|c|c|c|}
\hline $\begin{array}{c}\text { Dependent Variable: } \\
\text { Population Growth Rate }\end{array}$ & $\begin{array}{c}\text { (1) } \\
\text { OLS } \\
\end{array}$ & $\begin{array}{c}\text { (2) } \\
\text { OLS }\end{array}$ & $\begin{array}{c}\text { (3) } \\
\text { Fixed Effects } \\
\text { (City) }\end{array}$ & $\begin{array}{c}\text { (4) } \\
\text { Fixed Effects } \\
\text { (City) }\end{array}$ \\
\hline $\begin{array}{l}\text { MA * After reform * Low income } \\
\quad(\text { Treatment G3D) }\end{array}$ & $\begin{array}{c}0.0342 \\
(0.0215)\end{array}$ & $\begin{array}{c}0.0341 \\
(0.0213)\end{array}$ & $\begin{array}{l}0.0343^{*} \\
(0.0205)\end{array}$ & $\begin{array}{l}0.0343 * \\
(0.0203)\end{array}$ \\
\hline After reform (Year>2006) & $\begin{array}{l}0.0118 * * \\
(0.0056)\end{array}$ & $\begin{array}{l}0.0044 \\
(0.0061)\end{array}$ & $\begin{array}{l}0.0118 * \\
(0.0060)\end{array}$ & $\begin{array}{c}0.0041 \\
(0.0068)\end{array}$ \\
\hline Low-income $(<\$ 10 \mathrm{~K})$ & $\begin{array}{c}-0.1121 * * * \\
(0.0066)\end{array}$ & $\begin{array}{l}-0.1121 * * * \\
(0.0067)\end{array}$ & $\begin{array}{c}-0.1121 * * * \\
(0.0077)\end{array}$ & $\begin{array}{c}-0.1121 * * * \\
(0.0077)\end{array}$ \\
\hline MA & $\begin{array}{l}0.0240 * * * \\
(0.0081)\end{array}$ & $\begin{array}{l}0.0284 * * * \\
(0.0087)\end{array}$ & & \\
\hline After reform $*$ Low income & $\begin{array}{l}0.5128 * * * \\
(0.0141)\end{array}$ & $\begin{array}{l}0.5128 * * * \\
(0.0141)\end{array}$ & $\begin{array}{l}0.5128 * * * \\
(0.0133)\end{array}$ & $\begin{array}{c}0.5128 * * * \\
(0.0133)\end{array}$ \\
\hline After reform $*$ MA & $\begin{array}{l}-0.0040 \\
(0.0097)\end{array}$ & $\begin{array}{c}0.0110 \\
(0.0092)\end{array}$ & $\begin{array}{l}-0.0043 \\
(0.0103)\end{array}$ & $\begin{array}{c}0.0031 \\
(0.0107)\end{array}$ \\
\hline Low income * MA & $\begin{array}{l}-0.0197 * \\
(0.0114)\end{array}$ & $\begin{array}{l}-0.0198 * \\
(0.0115)\end{array}$ & $\begin{array}{l}-0.0196 \\
(0.0123) \\
\end{array}$ & $\begin{array}{l}-0.0196 \\
(0.0122)\end{array}$ \\
\hline Control variables? & No & Yes & No & Yes \\
\hline $\mathrm{N}$ & 2165 & 2165 & 2165 & 2165 \\
\hline Adjusted R-Squared & 0.71 & 0.71 & 0.73 & 0.74 \\
\hline $\mathrm{F}($ all covariates $)$ & $471.75 * * *$ & $292.76 * * *$ & $627.06 * * *$ & $363.73 * * *$ \\
\hline $\begin{array}{l}\text { Mean dependent variable } \\
\text { [Standard deviation] }\end{array}$ & $\begin{array}{c}0.1776 \\
{[0.2443]} \\
\end{array}$ & $\begin{array}{c}0.1776 \\
{[0.2443]} \\
\end{array}$ & $\begin{array}{c}0.1776 \\
{[0.2443]} \\
\end{array}$ & $\begin{array}{c}0.1776 \\
{[0.2443]} \\
\end{array}$ \\
\hline
\end{tabular}

Note: Robust standard errors are in parentheses, and all models have a constant term. Control variables include: the percentage change in the unemployment rate in a city, the number of violent crimes in a county, per pupil public expenditures in a county, average wages across industries in a county, and indicator variables (i.e. "flag" variables) for cities with missing values for each of these control variables. Cities with missing values for any of the control variables received value zero for that variable. The data cover one year before the reform (2005) and one year after the reform (2007). Significance levels: $*=\mathrm{p}<0.10, * *=\mathrm{p}<0.05, * * *=\mathrm{p}<0.01$. 
Table 6: Regression Results of Border Analysis DID models: Comparing Individuals Who Made Less Than \$10K in Border Versus Non-border Cities of Massachusetts

\begin{tabular}{|c|c|c|c|c|}
\hline $\begin{array}{l}\text { Dependent Variable: } \\
\text { Population Growth Rate }\end{array}$ & $\begin{array}{c}\text { (1) } \\
\text { OLS }\end{array}$ & $\begin{array}{c}\text { (2) } \\
\text { OLS }\end{array}$ & $\begin{array}{c}\text { (3) } \\
\text { Fixed Effects } \\
\text { (City) }\end{array}$ & $\begin{array}{c}\text { (4) } \\
\text { Fixed Effects } \\
\text { (City) }\end{array}$ \\
\hline $\begin{array}{l}\text { Border city }(0-5 \text { miles) *After reform } \\
\quad \text { (Treatment BDID5) }\end{array}$ & $\begin{array}{c}0.1907 * * * \\
(0.0472)\end{array}$ & $\begin{array}{c}0.1960 * * * \\
(0.0488)\end{array}$ & $\begin{array}{c}0.1914 * * * \\
(0.0450)\end{array}$ & $\begin{array}{c}0.1847 * * * \\
(0.0438)\end{array}$ \\
\hline $\begin{array}{l}\text { Border city }(5-10 \text { miles }) * \text { After reform } \\
\quad(\text { Treatment BDID10) }\end{array}$ & $\begin{array}{c}0.1301 * * * \\
(0.0390)\end{array}$ & $\begin{array}{c}0.1227 * * * \\
(0.0397)\end{array}$ & $\begin{array}{c}0.1301 * * * \\
(0.0392)\end{array}$ & $\begin{array}{c}0.1072 * * \\
(0.0428)\end{array}$ \\
\hline $\begin{array}{l}\text { Border city (10-15 miles) *After reform } \\
\quad(\text { Treatment BDID15) }\end{array}$ & $\begin{array}{c}0.0643 \\
(0.0412)\end{array}$ & $\begin{array}{c}0.0658 \\
(0.0425)\end{array}$ & $\begin{array}{c}0.0643 \\
(0.0418)\end{array}$ & $\begin{array}{c}0.0512 \\
(0.0449)\end{array}$ \\
\hline $\begin{array}{l}\text { Border city (15-20 miles) *After reform } \\
\text { (Treatment BDID20) }\end{array}$ & $\begin{array}{c}0.0396 \\
(0.0405)\end{array}$ & $\begin{array}{c}0.0564 \\
(0.0394)\end{array}$ & $\begin{array}{c}0.0396 \\
(0.0418)\end{array}$ & $\begin{array}{c}0.0375 \\
(0.0394)\end{array}$ \\
\hline $\begin{array}{l}\text { Border city (20-25 miles) *After reform } \\
\quad(\text { Treatment BDID25) }\end{array}$ & $\begin{array}{l}-0.0048 \\
(0.0484)\end{array}$ & $\begin{array}{c}0.0160 \\
(0.0492)\end{array}$ & $\begin{array}{l}-0.0048 \\
(0.0519)\end{array}$ & $\begin{array}{l}-0.0036 \\
(0.0560)\end{array}$ \\
\hline After reform (Year>2006) & $\begin{array}{c}0.4803 * * * \\
(0.0283)\end{array}$ & $\begin{array}{c}0.4707 * * * \\
(0.0284)\end{array}$ & $\begin{array}{c}0.4803 * * * \\
(0.0291)\end{array}$ & $\begin{array}{c}0.4820 * * * \\
(0.0267)\end{array}$ \\
\hline Border city: 0-5 miles & $\begin{array}{c}0.0152 \\
(0.0103)\end{array}$ & $\begin{array}{c}0.0185 \\
(0.0149)\end{array}$ & & \\
\hline Border city: 5-10 miles & $\begin{array}{l}0.0253 * \\
(0.0132)\end{array}$ & $\begin{array}{l}0.0304 * \\
(0.0170)\end{array}$ & & \\
\hline Border city: 10-15 miles & $\begin{array}{l}0.0228^{* *} \\
(0.0101)\end{array}$ & $\begin{array}{l}0.0297 * * \\
(0.0138)\end{array}$ & & \\
\hline Border city: $15-20$ miles & $\begin{array}{c}0.0094 \\
(0.0100)\end{array}$ & $\begin{array}{c}0.0014 \\
(0.0130)\end{array}$ & & \\
\hline Border city: $20-25$ miles & $\begin{array}{c}0.0414 \\
(0.0304)\end{array}$ & $\begin{array}{c}0.0410 \\
(0.0341)\end{array}$ & & \\
\hline $\begin{array}{l}\text { Control variables? } \\
\text { N } \\
\text { Adjusted R-Squared } \\
\text { F(all covariates) }\end{array}$ & $\begin{array}{c}\text { No } \\
674 \\
0.72 \\
198.97 * * *\end{array}$ & $\begin{array}{c}\text { Yes } \\
674 \\
0.73 \\
150.28 * * *\end{array}$ & $\begin{array}{c}\text { No } \\
674 \\
0.71 \\
323.95^{* * *}\end{array}$ & $\begin{array}{c}\text { Yes } \\
674 \\
0.73 \\
165.21^{* * *}\end{array}$ \\
\hline $\begin{array}{l}\text { Mean dependent variable } \\
\text { [Standard deviation] }\end{array}$ & $\begin{array}{c}0.2562 \\
{[0.3320]}\end{array}$ & $\begin{array}{c}0.2562 \\
{[0.3320]}\end{array}$ & $\begin{array}{c}0.2562 \\
{[0.3320]}\end{array}$ & $\begin{array}{c}0.2562 \\
{[0.3320]}\end{array}$ \\
\hline
\end{tabular}

Note: Robust standard errors are in parentheses, and all models have a constant term. Control variables include: the percentage change in the unemployment rate in a city, the number of violent crimes in a county, per pupil public expenditures in a county, average wages across industries in a county, and indicator variables (i.e. "flag" variables) for cities with missing values for each of these control variables. Cities with missing values for any of the control variables receive the value zero for that variable. The data cover one year before the reform (2005) and one year after the reform (2007). Significance levels: $*=p<0.10, * *=p<0.05, * * *=p<0.01$. 
Table 7: Regression Results of Border Analysis Triple-differences Models: Comparing Population Growth Rates of Individuals Who Made Less Than \$10K in Border Versus Non-border Cities of Massachusetts and Using the Population Growth Rate of Those Who Made More Than $\$ 100 \mathrm{~K}$ as the Third Dimension

\begin{tabular}{|c|c|c|c|c|}
\hline $\begin{array}{l}\text { Dependent Variable: } \\
\text { Population Growth Rate }\end{array}$ & $\begin{array}{c}\text { (1) } \\
\text { OLS } \\
\end{array}$ & $\begin{array}{c}\text { (2) } \\
\text { OLS }\end{array}$ & $\begin{array}{c}\text { (3) } \\
\text { Fixed Effects } \\
\text { (City) }\end{array}$ & $\begin{array}{c}\text { (4) } \\
\text { Fixed Effects } \\
\text { (City) }\end{array}$ \\
\hline $\begin{array}{l}\text { Border city }(0-5 \text { miles }) * \text { After reform * } \\
\quad \text { Low income (Treatment B3D5) }\end{array}$ & $\begin{array}{l}0.2252 * * * \\
(0.0502)\end{array}$ & $\begin{array}{l}0.2239 * * * \\
(0.0503)\end{array}$ & $\begin{array}{c}0.2285 * * * \\
(0.0494)\end{array}$ & $\begin{array}{c}0.2284 * * * \\
(0.0488)\end{array}$ \\
\hline $\begin{array}{l}\text { Border city (5-10 miles) *After reform * } \\
\quad \text { Low income (Treatment B3D10) }\end{array}$ & $\begin{array}{c}0.1488 * * * \\
(0.0536)\end{array}$ & $\begin{array}{c}0.1488 * * * \\
(0.0533)\end{array}$ & $\begin{array}{l}0.1488 * * * \\
(0.0503)\end{array}$ & $\begin{array}{l}0.1488 * * * \\
(0.0495)\end{array}$ \\
\hline $\begin{array}{l}\text { Border city (10-15 miles) *After reform * } \\
\quad \text { Low income (Treatment B3D15) }\end{array}$ & $\begin{array}{l}0.0817 * \\
(0.0451)\end{array}$ & $\begin{array}{l}0.0817 * \\
(0.0451)\end{array}$ & $\begin{array}{l}0.0817^{*} \\
(0.0443)\end{array}$ & $\begin{array}{l}0.0817^{*} \\
(0.0441)\end{array}$ \\
\hline $\begin{array}{l}\text { Border city (15-20 miles) *After reform * } \\
\quad \text { Low income (Treatment B3D20) }\end{array}$ & $\begin{array}{c}0.0697 \\
(0.0432)\end{array}$ & $\begin{array}{l}0.0697 * \\
(0.0421)\end{array}$ & $\begin{array}{c}0.0697 \\
(0.0433)\end{array}$ & $\begin{array}{l}0.0697 * \\
(0.0420)\end{array}$ \\
\hline $\begin{array}{l}\text { Border city }(20-25 \text { miles }) * \text { After reform * } \\
\text { Low income (Treatment B3D25) }\end{array}$ & $\begin{array}{c}0.0062 \\
(0.0518)\end{array}$ & $\begin{array}{c}0.0062 \\
(0.0516)\end{array}$ & $\begin{array}{c}0.0062 \\
(0.0515)\end{array}$ & $\begin{array}{c}0.0062 \\
(0.0506)\end{array}$ \\
\hline $\begin{array}{l}\text { Control variables? } \\
\text { N } \\
\text { Adjusted R-Squared } \\
\text { F(all covariates) }\end{array}$ & $\begin{array}{c}\text { No } \\
1345 \\
0.68 \\
116.31 * * *\end{array}$ & $\begin{array}{c}\text { Yes } \\
1345 \\
0.69 \\
99.69 * * *\end{array}$ & $\begin{array}{c}\text { No } \\
1345 \\
0.70 \\
124.86^{* * *}\end{array}$ & $\begin{array}{c}\text { Yes } \\
1345 \\
0.71 \\
107.71 * * *\end{array}$ \\
\hline $\begin{array}{l}\text { Mean dependent variable } \\
\text { [Standard deviation] }\end{array}$ & $\begin{array}{c}0.1855 \\
{[0.2561]}\end{array}$ & $\begin{array}{c}0.1855 \\
{[0.2561]}\end{array}$ & $\begin{array}{c}0.1855 \\
{[0.2561]}\end{array}$ & $\begin{array}{c}0.1855 \\
{[0.2561]}\end{array}$ \\
\hline
\end{tabular}

Note: Robust standard errors are in parentheses. Models 1 and 2 include a set of indicator variables for cities located at various distances from the border (i.e. 0-5 miles, 5-10miles, 10-15 miles, 15-20 miles, and 20-25 miles), which are dropped in models 3 and 4 due to the presence of fixed effects. All models have a constant term, an indicator variable for post reform observations (i.e. After reform), an indicator variable for observations related to the lowincome group (i.e. Low income), an interaction term between After reform and Low income variables, and a set of interaction terms between After reform (also Low income) and the indicator variables for border cities. Control variables include: the percentage change in the unemployment rate in a city, the number of violent crimes in a county, per pupil public expenditures in a county, average wages across industries in a county, and indicator variables (i.e. "flag" variables) for cities with missing values for each of these control variables. Cities with missing values for any of the control variables receive the value zero for that variable. The data cover one year before the reform (2005) and one year after the reform (2007). Significance levels: * $=p<0.10, * *=p<0.05, * * *=p<0.01$. 
Table 8: Regression Results of Border Analysis Triple-differences Models: Comparing Population Growth Rates of Individuals Who Made Less Than \$10K in Border Versus Non-border Cities of Massachusetts and Using Border Versus Non-border Cities in Connecticut and Rhode Island (combined) as the Third Dimension

\begin{tabular}{|c|c|c|c|c|}
\hline $\begin{array}{l}\text { Dependent Variable: } \\
\text { Population Growth Rate }\end{array}$ & $\begin{array}{c}\text { (1) } \\
\text { OLS } \\
\end{array}$ & $\begin{array}{c}\text { (2) } \\
\text { OLS } \\
\end{array}$ & $\begin{array}{c}\text { (3) } \\
\text { Fixed Effects } \\
\text { (City) }\end{array}$ & $\begin{array}{c}\text { (4) } \\
\text { Fixed Effects } \\
\text { (City) }\end{array}$ \\
\hline $\begin{array}{l}\text { Border city }(0-5 \text { miles }) * \text { After reform * } \\
\text { MA (Treatment B3D5) }\end{array}$ & $\begin{array}{c}0.2303 * * * \\
(0.0606)\end{array}$ & $\begin{array}{l}0.2639 * * * \\
(0.0617)\end{array}$ & $\begin{array}{c}0.2309 * * * \\
(0.0612)\end{array}$ & $\begin{array}{c}0.2497 * * * \\
(0.0593)\end{array}$ \\
\hline $\begin{array}{l}\text { Border city (5-10 miles) *After reform * } \\
\text { MA (Treatment B3D10) }\end{array}$ & $\begin{array}{c}0.2047 * * * \\
(0.0551)\end{array}$ & $\begin{array}{l}0.2255^{* * *} * \\
(0.0544)\end{array}$ & $\begin{array}{l}0.2047 * * * \\
(0.0554)\end{array}$ & $\begin{array}{l}0.2060 * * * \\
(0.0563)\end{array}$ \\
\hline $\begin{array}{l}\text { Border city (10-15 miles) *After reform * } \\
\quad \text { MA (Treatment B3D15) }\end{array}$ & $\begin{array}{c}0.1594 * * * \\
(0.0565)\end{array}$ & $\begin{array}{c}0.1947 * * * \\
(0.0583)\end{array}$ & $\begin{array}{l}0.1594 * * * \\
(0.0589)\end{array}$ & $\begin{array}{l}0.1767 * * * \\
(0.0624)\end{array}$ \\
\hline $\begin{array}{l}\text { Border city (15-20 miles) *After reform * } \\
\quad \text { MA (Treatment B3D20) }\end{array}$ & $\begin{array}{c}0.0482 \\
(0.0621)\end{array}$ & $\begin{array}{c}0.0821 \\
(0.0609)\end{array}$ & $\begin{array}{c}0.0482 \\
(0.0626)\end{array}$ & $\begin{array}{c}0.0588 \\
(0.0620)\end{array}$ \\
\hline $\begin{array}{l}\text { Border city (20-25 miles) *After reform * } \\
\quad \text { MA (Treatment B3D25) }\end{array}$ & $\begin{array}{l}-0.0352 \\
(0.0621)\end{array}$ & $\begin{array}{c}0.0002 \\
(0.0637)\end{array}$ & $\begin{array}{l}-0.0352 \\
(0.0629)\end{array}$ & $\begin{array}{l}-0.0258 \\
(0.0666)\end{array}$ \\
\hline $\begin{array}{l}\text { Control variables? } \\
\mathrm{N} \\
\text { Adjusted R-Squared } \\
\mathrm{F} \text { (all covariates) }\end{array}$ & $\begin{array}{c}\text { No } \\
1084 \\
0.74 \\
187.38 * * * \\
\end{array}$ & $\begin{array}{c}\text { Yes } \\
1084 \\
0.75 \\
157.58 * * * \\
\end{array}$ & $\begin{array}{c}\text { No } \\
1084 \\
0.74 \\
323.54 * * * \\
\end{array}$ & $\begin{array}{c}\text { Yes } \\
1084 \\
0.75 \\
190.68 * * * \\
\end{array}$ \\
\hline $\begin{array}{l}\text { Mean dependent variable } \\
\text { [Standard deviation] }\end{array}$ & $\begin{array}{c}0.2489 \\
{[0.3180]}\end{array}$ & $\begin{array}{c}0.2489 \\
{[0.3180]}\end{array}$ & $\begin{array}{c}0.2489 \\
{[0.3180]}\end{array}$ & $\begin{array}{c}0.2489 \\
{[0.3180]}\end{array}$ \\
\hline
\end{tabular}

Note: Robust standard errors are in parentheses. Models 1 and 2 include a set of indicator variables for cities located at various distances from the border (i.e. 0-5 miles, 5-10miles, 10-15 miles, 15-20 miles, and 20-25 miles), which are dropped in models 3 and 4 due to the presence of fixed effects. All models have a constant term, an indicator variable for post-reform observations (i.e. After reform), an indicator variable for observations on cities in Massachusetts (i.e. MA), an interaction term between After reform and MA variables, and a set of interaction terms between After reform (also MA) and the indicator variables for border cities. Control variables include: the percentage change in the unemployment rate in a city, the number of violent crimes in a county, per pupil public expenditures in a county, average wages across industries in a county, and indicator variables (i.e. "flag" variables) for cities with missing values for each of these control variables. Cities with missing values for any of the control variables receive the value zero for that variable. The data cover one year before the reform (2005) and one year after the reform (2007). Significance levels: $*=p<0.10, * *=p<0.05, * * *=p<0.01$. 
Table 9: Regression Results of Border Analysis Triple-differences Models: Comparing Population Growth Rates of Individuals Who Made Less Than \$10K in Border Versus Non-border Cities of Massachusetts and Using Border Versus Non-border Cities in Connecticut, Rhode Island, New York, New Hampshire, and Vermont (combined) as the Third Dimension

\begin{tabular}{|c|c|c|c|c|}
\hline $\begin{array}{l}\text { Dependent Variable: } \\
\text { Population Growth Rate }\end{array}$ & $\begin{array}{l}\text { (1) } \\
\text { OLS }\end{array}$ & $\begin{array}{l}(2) \\
\text { OLS }\end{array}$ & $\begin{array}{c}\text { (3) } \\
\text { Fixed Effects } \\
(\text { City })\end{array}$ & $\begin{array}{c}\text { (4) } \\
\text { Fixed Effects } \\
\text { (City) }\end{array}$ \\
\hline $\begin{array}{l}\text { Border city }(0-5 \text { miles) *After reform * } \\
\text { MA (Treatment B3D5) }\end{array}$ & $\begin{array}{l}0.1960 * * * \\
(0.0566)\end{array}$ & $\begin{array}{l}0.2168 * * * \\
(0.0568)\end{array}$ & $\begin{array}{c}0.1969 * * * \\
(0.0552)\end{array}$ & $\begin{array}{c}0.1989 * * * \\
(0.0549)\end{array}$ \\
\hline $\begin{array}{l}\text { Border city (5-10 miles) *After reform * } \\
\quad \text { MA (Treatment B3D10) }\end{array}$ & $\begin{array}{c}0.0999 \\
(0.1231)\end{array}$ & $\begin{array}{c}0.1278 \\
(0.1250)\end{array}$ & $\begin{array}{l}0.2197 * * * \\
(0.0480)\end{array}$ & $\begin{array}{l}0.2314 * * * \\
(0.0481)\end{array}$ \\
\hline $\begin{array}{l}\text { Border city (10-15 miles) *After reform * } \\
\quad \text { MA (Treatment B3D15) }\end{array}$ & $\begin{array}{l}0.1405 * * * \\
(0.0496)\end{array}$ & $\begin{array}{c}0.1643 * * * \\
(0.0496)\end{array}$ & $\begin{array}{l}0.1407 * * * \\
(0.0505)\end{array}$ & $\begin{array}{l}0.1455^{* * * *} \\
(0.0510)\end{array}$ \\
\hline $\begin{array}{l}\text { Border city (15-20 miles) *After reform * } \\
\quad \text { MA (Treatment B3D20) }\end{array}$ & $\begin{array}{l}0.1295 * * * \\
(0.0497)\end{array}$ & $\begin{array}{c}0.1574 * * * \\
(0.0495)\end{array}$ & $\begin{array}{l}0.1297 * * \\
(0.0513)\end{array}$ & $\begin{array}{c}0.1353 * * * \\
(0.0511)\end{array}$ \\
\hline $\begin{array}{l}\text { Border city (20-25 miles) *After reform * } \\
\quad \text { MA (Treatment B3D25) }\end{array}$ & $\begin{array}{c}0.0378 \\
(0.0558)\end{array}$ & $\begin{array}{c}0.0608 \\
(0.0573)\end{array}$ & $\begin{array}{c}0.0380 \\
(0.0600)\end{array}$ & $\begin{array}{c}0.0372 \\
(0.0615)\end{array}$ \\
\hline $\begin{array}{l}\text { Control variables? } \\
\mathrm{N} \\
\text { Adjusted R-Squared } \\
\mathrm{F} \text { (all covariates) } \\
\end{array}$ & $\begin{array}{c}\text { No } \\
3406 \\
0.32 \\
281.07 * * * \\
\end{array}$ & $\begin{array}{c}\text { Yes } \\
3406 \\
0.32 \\
236.83 * * * \\
\end{array}$ & $\begin{array}{c}\text { No } \\
3406 \\
0.74 \\
423.36^{* * *} \\
\end{array}$ & $\begin{array}{c}\text { Yes } \\
3406 \\
0.74 \\
257.78 * * * \\
\end{array}$ \\
\hline $\begin{array}{l}\text { Mean dependent variable } \\
\text { [Standard deviation] }\end{array}$ & $\begin{array}{c}0.2579 \\
{[0.4781]}\end{array}$ & $\begin{array}{c}0.2579 \\
{[0.4781]}\end{array}$ & $\begin{array}{c}0.2579 \\
{[0.4781]}\end{array}$ & $\begin{array}{c}0.2579 \\
{[0.4781]}\end{array}$ \\
\hline
\end{tabular}

Note: Robust standard errors are in parentheses. Models 1 and 2 include a set of indicator variables for cities located at various distances from the border (i.e. 0-5 miles, 5-10miles, 10-15 miles, 15-20 miles, and 20-25 miles), which are dropped in models 3 and 4 due to the presence of fixed effects. All models have a constant term, an indicator variable for post-reform observations (i.e. After reform), an indicator variable for observations on cities in Massachusetts (i.e. MA), an interaction term between After reform and MA variables, and a set of interaction terms between After reform (also MA) and the indicator variables for border cities. Control variables include: percentage change in the value of the unemployment rate in a city, the number of violent crimes in a county, per pupil public expenditures in a county, average wages across industries in a county, and indicator variables (i.e. "flag" variables) for cities with missing values for each of these control variables. Cities with missing values for any of the control variables receive the value zero for that variable. The data cover one year before the reform (2005) and one year after the reform (2007). Significance levels: $*=p<0.10,{ }^{*}=p<0.05, * * *=p<0.01$. 
Table 10: Pseudo-regression Results of Border Analysis Triple-differences Models: Comparing Population Growth Rates of Individuals Who Made More Than \$100K in Border Versus Non-border Cities of Massachusetts and Using Border Versus Non-border Cities in Connecticut, Rhode Island, New York, New Hampshire, and Vermont (combined) as the Third Dimension

\begin{tabular}{|c|c|c|c|c|}
\hline $\begin{array}{l}\text { Dependent Variable: } \\
\text { Population Growth Rate }\end{array}$ & $\begin{array}{c}(1) \\
\text { OLS }\end{array}$ & $\begin{array}{c}(2) \\
\text { OLS }\end{array}$ & $\begin{array}{c}\text { (3) } \\
\text { Fixed Effects } \\
(\text { City })\end{array}$ & $\begin{array}{c}\text { (4) } \\
\text { Fixed Effects } \\
\text { (City) }\end{array}$ \\
\hline $\begin{array}{l}\text { Border city }(0-5 \text { miles }) * \text { After reform * } \\
\text { MA (Treatment B3D5) }\end{array}$ & $\begin{array}{c}0.0004 \\
(0.0229)\end{array}$ & $\begin{array}{l}-0.0016 \\
(0.0242)\end{array}$ & $\begin{array}{l}-0.0033 \\
(0.0203)\end{array}$ & $\begin{array}{l}-0.0056 \\
(0.0208)\end{array}$ \\
\hline $\begin{array}{l}\text { Border city (5-10 miles) *After reform * } \\
\quad \text { MA (Treatment B3D10) }\end{array}$ & $\begin{array}{l}-0.1303 \\
(0.1513)\end{array}$ & $\begin{array}{l}-0.1299 \\
(0.1536)\end{array}$ & $\begin{array}{c}0.0091 \\
(0.0334)\end{array}$ & $\begin{array}{c}0.0051 \\
(0.0315)\end{array}$ \\
\hline $\begin{array}{l}\text { Border city (10-15 miles) *After reform * } \\
\quad \text { MA (Treatment B3D15) }\end{array}$ & $\begin{array}{c}0.0247 \\
(0.0289)\end{array}$ & $\begin{array}{c}0.0216 \\
(0.0296)\end{array}$ & $\begin{array}{c}0.0247 \\
(0.0263)\end{array}$ & $\begin{array}{c}0.0219 \\
(0.0270)\end{array}$ \\
\hline $\begin{array}{l}\text { Border city (15-20 miles) *After reform * } \\
\quad \text { MA (Treatment B3D20) }\end{array}$ & $\begin{array}{c}0.0006 \\
(0.0271)\end{array}$ & $\begin{array}{c}0.0060 \\
(0.0280)\end{array}$ & $\begin{array}{c}0.0009 \\
(0.0235)\end{array}$ & $\begin{array}{c}0.0014 \\
(0.0246)\end{array}$ \\
\hline $\begin{array}{l}\text { Border city (20-25 miles) *After reform * } \\
\quad \text { MA (Treatment B3D25) }\end{array}$ & $\begin{array}{c}0.0213 \\
(0.0279)\end{array}$ & $\begin{array}{c}0.0342 \\
(0.0288)\end{array}$ & $\begin{array}{c}0.0087 \\
(0.0212)\end{array}$ & $\begin{array}{c}0.0126 \\
(0.0218)\end{array}$ \\
\hline $\begin{array}{l}\text { Control variables? } \\
\mathrm{N} \\
\text { Adjusted R-Squared } \\
\mathrm{F} \text { (all covariates) } \\
\end{array}$ & $\begin{array}{c}\text { No } \\
3209 \\
-0.00 \\
3.52 * * * \\
\end{array}$ & $\begin{array}{c}\text { Yes } \\
3209 \\
-0.00 \\
3.51 * * * \\
\end{array}$ & $\begin{array}{c}\text { No } \\
3209 \\
0.92 \\
2.85^{* * *} \\
\end{array}$ & $\begin{array}{c}\text { Yes } \\
3209 \\
0.92 \\
2.10^{* * *}\end{array}$ \\
\hline $\begin{array}{l}\text { Mean dependent variable } \\
\text { [Standard deviation] }\end{array}$ & $\begin{array}{c}0.1335 \\
{[0.4229]}\end{array}$ & $\begin{array}{c}0.1335 \\
{[0.4229]}\end{array}$ & $\begin{array}{c}0.1335 \\
{[0.4229]}\end{array}$ & $\begin{array}{c}0.1335 \\
{[0.4229]}\end{array}$ \\
\hline
\end{tabular}

Note: Robust standard errors are in parentheses. Models 1 and 2 include a set of indicator variables for cities located at various distances from the border (i.e. 0-5 miles, 5-10miles, 10-15 miles, 15-20 miles, and 20-25 miles), which are dropped in models 3 and 4 due to the presence of fixed effects. All models have a constant term, an indicator variable for post-reform observations (i.e. After reform), an indicator variable for observations on cities in Massachusetts (i.e. MA), an interaction term between After reform and MA variables, and a set of interaction terms between After reform (also MA) and the indicator variables for border cities. Control variables include: the percentage change in the unemployment rate in a city, the number of violent crimes in a county, per pupil public expenditures in a county, average wages across industries in a county, and indicator variables (i.e. "flag" variables) for cities with missing values for each of these control variables. Cities with missing values for any of the control variables receive the value zero for that variable. The data cover one year before the reform (2005) and one year after the reform (2007). Significance levels: $*=p<0.10, * *=p<0.05, * * *=p<0.01$. 